\title{
Statistical Dèjá Vu: The National Data Center Proposal of 1965 and Its Descendants
}

\author{
Rebecca S. Kraus, Ph.D.*
}

\section{Introduction: Computers, Researchers, and the Need for Data}

In the early 1960s, social scientists recognized the need for greater access to microdata maintained by the federal government. Computer technology had improved the efficiency and affordability of research with large data sets, and the expansion of government social programs called for more data and research to inform public policy. As a result, in 1965 social scientists recommended that the federal government develop a national data center that would store and make available to researchers the data collected by various statistical agencies. Because of its massive data holdings and its pioneering work in the use of computers for the storage and analysis of data, the Census Bureau became involved in the national debate, though reluctantly.

The government's endorsement of the national data center proposal led to public outcry and intense congressional scrutiny over the data on individuals maintained by federal agencies, potential misuse of such data, and threats to privacy posed by emerging technologies. One key lesson of the data center debate is that social scientists and government agencies must consider the practical implications of their plans and clearly communicate those plans to the public. Although the research community and the government understood the potential benefits of a national data center, and agreed that the data would be used only for research, a significant portion of the public seemed not to share their enthusiasm for a national data center. Fears of "Big Brother" and secret government dossiers swirled around discussions of the national data center, and the issue became identified with other concerns about invasions of privacy ranging from psychological testing to illegal wire tapping, culminating in the passage of the Privacy Act of 1974 .

While a national data center ultimately was not created, advances in technology and statistical methodology have led to greater data sharing and linkage capabilities. Intense political scrutiny of federal statistics has resurfaced occasionally, as have discussions concerning centralization of statistical functions. What can we learn from 1965 that can help us form sound statistical information policies in the $21^{\text {st }}$ century?

*U.S. Census Bureau, Washington D.C., mailto:rebecca.s.kraus@census.gov 


\subsection{Technological Advancements and Access to Government Data}

The national data center proposal came at a time when the Census Bureau was already investigating ways to make its data more readily available to outside researchers. In the late 1950s, the Consultant Committee on Consumer Survey Statistics, ${ }^{1}$ the Associated University Bureaus of Business and Economic Research, and other groups asked the agency to consider ways to make more of its data, including data withheld because of disclosure policies, available to researchers. ${ }^{2}$ Around the same time, because of the lack of a congressional appropriation for the 1953 Economic Census, the Secretary of Commerce established the Intensive Review Committee to determine needs and uses of census data. ${ }^{3}$ The committee recommended that the Census Bureau continue to consult with its customers to determine user needs. In particular, the committee suggested the agency hold informal meetings with data users to discuss their needs for data. ${ }^{4}$ In response, the agency held meetings in several cities beginning in May 1955 to obtain researcher input on 1960 censuses of population, housing, and agriculture. ${ }^{5}$

In the late 1950s, the Office of Statistical Standards (OSS) of the Bureau of the Budget (BoB) began working with the American Statistical Association (ASA) Advisory Committee to the Bureau of the Budget on Statistical Policy to establish principles for access to federal data sets by nongovernmental researchers. ${ }^{6}$ The OSS circulated a draft statement of the principles to the statistical agencies for their input. In 1957, the director of the Census Bureau, Robert W. Burgess, commented on the draft policy and provided an overview of the agency's policy concerning providing data to outside researchers, noting that:

Sometimes, the private research worker needs additional information not available in published form, and the Bureau believes that it serves the public interest when it makes a special tabulation and provides that information. With the expansion of its electronic facilities, it hopes to extend its services and provide more information to researcher workers.

On the other hand, we are just as firm in believing that it is in the public interest to protect the rights of respondents and to keep their replies confidential. Few research workers would wish to relax the disclosure rules to

\footnotetext{
${ }^{1}$ This committee was organized by the Board of Governors of the Federal Reserve System at the request of the Subcommittee on Economic Statistics of the Joint Committee on the Economic Report.

${ }^{2}$ U.S. Census Bureau, "Bureau of the Census Statement on Disclosure of Confidential Information: A White Paper for the Census Advisory Committee of the American Statistical Association," draft, Oct. $5,1956$.

${ }^{3}$ Robert B. Voight, Bureau of the Census, "Developments in Making Census Data More Useful," paper given at the Federal Statistics User Conference, Washington, D.C., Oct. 20, 1967.

${ }^{4}$ Appraisal of Census Programs: Report of the Intensive Review Committee to the Secretary of Commerce, February 1954, p. 14 (recommendation 43), accessed at http://www.census.gov/history/ pdf/WatkinsComReport.pdf

${ }^{5}$ Howard G. Brunsman, "Federal Statistical Activities: Local Meetings with Users of Census Data," The American Statistician, vol. 9, no. 5 (December 1955), p. 5. The meetings were coordinated with local chapters of organizations such as the American Statistical Association and the American Marketing Association. Meetings were held in New York City (May 2-3), Baltimore (September 29), Chicago (October 17), St. Louis (October 19), and Detroit (November 17).
} 
the extent that this would lower the quality of the statistics. In such an event, no one would be harmed more than the research people themselves, and many of them, realizing this, have urged us to protect information given in confidence. ${ }^{7}$

The BoB finalized its statement regarding access to federal statistical materials for nongovernmental researchers in April 1959. The statement reflected much of the Census Bureau's existing policy. In particular, the Budget Bureau noted that requests for data "should be met as fully as possible by making special tabulations to the specifications of outside users." 8 The statement offered alternatives for those requests that could not be adequately met by special tabulations, such as permitting the researcher access to certain raw materials within the agency, taking "whatever steps are necessary to protect the confidentiality of the data supplied by individual respondents." 9 The BoB urged advance planning by federal agencies to permit maximum usage of the data they collected, noting: "any steps to make the survey procedure a matter of systematic record, intelligible to other competent research workers, will aid users to make valid use of the data." 10

In 1963, the ASA Census Advisory Committee recommended that the Census Bureau conduct research to determine the uses of its data products. ${ }^{11}$ The following year, the Census Advisory Committee of the American Economic Association (AEA), noting that the cost of special tabulations was often too high for university researchers, recommended that the Census Bureau investigate ways of making unpublished data available to outside researchers, such as by creating Census data centers at selected universities. ${ }^{12}$ The Census Bureau responded to such recommendations by creating a Task Force on Uses of Census Statistics in 1963. The task force was charged with reviewing existing information on the uses of census data and recommending additional steps for evaluating the uses of the statistics. ${ }^{13}$ Over the next several years, the Census Bureau examined options for the development of a data user program. For example, the Census Bureau created the Census Use Survey in 1966 and established the Data Access and

\footnotetext{
${ }^{6}$ The ASA committee, chaired by Ralph J. Watkins (who had chaired the Intensive Review Committee of the Department of Commerce from 1953 to 1954), assisted the Office of Statistical Standards of the Bureau of the Budget in preparing its statement concerning the availability of federal statistical materials to nongovernmental researchers. "Recommendations on Availability of Federal Statistical Materials to Nongovernmental Research Workers," The American Statistician, vol. 13, no. 4 (October 1959), p. 15. The BoB is the predecessor of the Office of Management and Budget, an agency within the Executive Office of the President.

${ }^{7}$ Robert W. Burgess, director, Bureau of the Census, letter to Raymond T. Bowman, assistant director for statistical standards, Bureau of the Budget, Executive Office of the President, April 19, 1957, p. 4.

${ }^{8}$ Executive Office of the President, Bureau of the Budget, "Availability of Federal Statistical Materials to Nongovernmental Research Workers: A Statement of Principles," April 3, 1959, Records of the Office of Management and Budget, Record Group 51 (RG 51), National Archives at College Park, College Park, MD.

${ }^{9}$ Ibid., p. 2.

${ }^{10}$ Ibid., pp. $2-3$.
} 
Use Laboratory the following year.

The increasing number of requests for data reflects the period of rapid growth in social science research that occurred in the 1950s and 1960s. In their history of the evolution of federal statistics, Joseph W. Duncan and William C. Shelton noted:

The development and widespread use of the electronic digital computer unquestionably has been one of the great technological changes in the third quarter of the $20^{\text {th }}$ century. One of its effects on statistics has been very large reductions in clerical personnel requirements and consequent large reductions in total cost. An effect which is probably even more important in the long run is the ability to do things which could not be done at all without computers, either because they could not be done in time to be useful or because they would have cost too much to be practical. ${ }^{14}$

Their statement echoed the Social Science Research Council's Committee on the Preservation and Use of Economic Data, which noted that "the technological revolution has become so great that a re-examination of the organization of the Federal statistical system is urgently needed." 15 In particular, with the use of computers, researchers were able to increase efficiency and reduce the time required for data processing. Computers also improved data quality and permitted new types of data analyses to be conducted. Because computers required less space to store data, it became feasible to store and maintain more data and larger data sets. ${ }^{16}$

These improvements resulted not only in time and space savings, but cost savings as well, enabling researchers to do more detailed research and respond more quickly to pressing social issues. At the same time, government programs designed to address social issues, such as civil rights, housing, employment, welfare, education, and poverty

${ }^{11}$ Richard M. Scammon, director, U.S. Census Bureau, Memorandum to All Divisions and Offices, Re: Task Force on Uses of Census Statistics, June 20, 1963; Voight, 1967, p. 1.

${ }^{12}$ Solomon Fabricant, "Report of the Census Advisory Committee," American Economic Review, vol. 55, no. 1/2 (March 1, 1965), pp. 619-620. The Census Bureau noted that it was already studying the feasibility of creating such centers but it still needed to resolve problems with regard to confidentiality and the high costs of providing data tapes that were complete and properly formatted. The AEA continued to explore this issue with the Census Bureau over the next several years. Solomon Fabricant, "Report of the Census Advisory Committee," American Economic Review, vol. 56, no. 1/2 (March 1, 1966), p. 642; Solomon Fabricant, "Report of the Census Advisory Committee," American Economic Review, vol. 57, no. 2 (May 1967), p. 720; Solomon Fabricant, Report of the Census Advisory Committee," American Economic Review, vol. 58, no. 2 (May 1968), p. 671; Solomon Fabricant, "Report of the Census Advisory Committee," American Economic Review, vol. 59, no. 2 (May 1969), p. 607.

${ }^{13}$ Scammon, 1963; Robert B. Voight, staff assistant, Director's Office, U.S. Census Bureau, Memorandum to All Division Chiefs, Re: Report on plans for the study of the use of Census Bureau statistics, Oct. 16, 1964.

${ }^{14}$ Joseph W. Duncan and William C. Shelton, Revolution in United States Government Statistics: 1926-1976, U.S. Department of Commerce, Office of Federal Statistical Policy and Standards, October 1978, p. 116

${ }^{15}$ Social Science Research Council (SSRC), Report of the Committee on the Preservation and Use of Economic Data, April 1965, p. 9.

${ }^{16}$ SSRC, pp. 8-14. 
called for more information and data on those issues. Often, the information needed was not available to researchers. ${ }^{17}$ As research needs grew and research capabilities expanded, the number of market and survey research organizations and university research institutions grew, further increasing the demand for data. ${ }^{18}$ These converging forces resulted in a call from the social science community for greater access to and greater preservation of socioeconomic data.

\subsection{The American Economic Association Discusses Access to Data}

At the 1959 annual meeting of the American Economic Association (AEA), members of the executive committee discussed the need for access to social and economic data for research purposes. Recognizing that the AEA was not equipped to address the problem, the executive committee asked the Social Science Research Council (SSRC) to study the issue. ${ }^{19}$ In December 1960, the SSRC held a meeting with social scientists both within and outside the federal government concerning the preservation and use of data. Although the attendees expressed interest in government data, there was no agreement on the best approach for preserving and using the data. Deeming the issue to be too broad, the SSRC decided to take a more focused approach.

Thus, the SSRC set up a committee to examine the problem with regard only to economic data. The scope was also limited to information in machine-readable form. The Committee on the Preservation and Use of Economic Data conducted a 3-year study of the availability of data collected by the federal government and its use in research. ${ }^{20}$ Between 1962 and 1964, the committee met with agencies within the Departments of Commerce, Labor, Treasury, Agriculture, Interior, and Health, Education, and Welfare, as well as the Bureau of the Budget and the National Archives.

\subsection{Recommendation for a National Data Center}

In April 1965, the SSRC Committee on the Preservation and Use of Economic Data issued their report, known as the Ruggles Report (named after the chairman of the committee, Yale economist Richard Ruggles). The report described the decentralized nature of the federal statistical system, noting the coordinating role of the Office of Statistical Standards of the BoB and the records management function of the National Archives and Records Service (now the National Archives and Records Administration). With regard to the decentralization of the federal statistical system, the committee

\footnotetext{
${ }^{17}$ The Coordination and Integration of Government Statistical Programs, hearings before the Subcomm. on Economic Statistics, Joint Economic Comm., 90th Cong, 1st Sess., May 17-18, June 7-8, 1967 (statement of John H. Aiken), p. 44.

${ }^{18}$ Ralph L. Bisco, "Social Science Data Archives: Progress and Prospects," Social Science Information, vol. 6 (1967), pp. 39-74.

${ }^{19}$ SSRC, p. 1; Duncan and Shelton, p. 175.

${ }^{20}$ The committee members were Richard Ruggles, Yale University, chairman; Richard Miller, Wesleyan University, secretary; Edwin Kuh, Massachusetts Institute of Technology; Stanley Lebergott, Wesleyan University; Guy Orcutt, University of Wisconsin; and Joseph Pechman, Brookings Institution.
} 
noted that much of the data collected was required for specific, operational purposes. ${ }^{21}$ The committee noted that 20 federal statistical agencies had over 600 major data sets that were stored on approximately 100 million punchcards and 30,000 computer tapes. This vast amount of data spread across many agencies made it difficult for researchers to access the data or even know what data existed, despite the fact that it had been collected at public expense. ${ }^{22}$

To resolve this issue, the committee recommended that the government establish a national data center to preserve data collected by its agencies and make the data available to researchers both within and outside the government. ${ }^{23}$ The committee identified several things necessary for the data center to function properly, including the authority to work collaboratively with other federal agencies, computer capabilities, and new administrative arrangements. The purpose of the data center would be to provide user services and basic information about the U.S. economy. As such, the center would need to "ensure that the most useful information was preserved in a usable form, and that duplicative and unwanted data did not clog the system." 24

In the committee's view, the federal data center would have the authority to obtain computer tapes produced by other agencies; thus, the center would "follow statistical projects and ... see that the clean edited tapes are made available within a reasonable period." 25 As part of its capabilities, the center would provide aggregate data or results to scholars on a reimbursable basis. ${ }^{26}$ Thus, it also would be necessary for center staff to be subject specialists so they could respond to researchers' questions about the data. Further, because of the decentralized nature of the federal statistical system, the committee recommended that a new administrative arrangement be developed for the data center. They recommended that the BoB begin planning and developing the data center immediately, recognizing that there may be a need for new legislative

\footnotetext{
${ }^{21}$ The committee noted that the Census Bureau "performs many of the functions normally undertaken by a central statistical office. The Census Bureau is responsible for comprehensive data on population, housing, agriculture, manufactures, retail and wholesale trade, transportation, and government bodies. This information provides other agencies with basic information about the American economy and its functioning ... Certain tasks formerly undertaken by other agencies, such as the collection of foreign trade statistics and labor force surveys, have become a regular part of the Census program." SSRC, pp. 6-7.

${ }^{22}$ Ibid., pp. $15,18$.

${ }^{23}$ Ibid.

${ }^{24}$ Ibid. p. 20.
} 
authorities. $^{27}$

\section{The Federal Government's Response}

In May 1965, Raymond T. Bowman of the Bureau of the Budget hired a consultant to review the SSRC recommendations and identify ways of implementing a national data center. ${ }^{28}$ As assistant director for statistical standards, Bowman was concerned with strengthening the federal statistical system and integrating the many statistical programs. He wrote extensively on statistical developments and endorsed the concept of a national data center. ${ }^{29}$

\subsection{The Dunn Report}

Bowman's consultant, Edgar S. Dunn, supported the national data center proposed in the Ruggles Report. ${ }^{30}$ Between June and November 1965, Dunn studied the use of statistical data in policy and decision making and the relationship between the collection of data and its preservation and accessibility for further use. In a December 1965 report, Dunn stated: "the greatest deficiency of the existing Federal Statistical System is its failure to permit the association of the elements of data sets in a way that identifies and measures the interrelationship among interdependent activities." ${ }^{31}$ He noted that the many data files were "quite different in terms of the organization, the levels of disaggregation required, and, most importantly, in the way the file needs to be associated

\footnotetext{
${ }^{25}$ Ibid., p. 19.

${ }^{26}$ Recognizing that much of the data collected by the federal government was obtained with a pledge of confidentiality, the committee stated providing aggregate data or results would avoid disclosure of confidential data. They also noted that "it is often possible to disguise the information in such a way that specific data cannot be traced to any individual respondent." SSRC, p. 17. The report referred to the Census Bureau's sample data on 100,000 households as an example of how "the omission of detailed geographic information makes it impossible to trace the data to any specific individual." SSRC, pp. 17-18. In the 1960s, the Census Bureau responded to researchers' requests for data by releasing the 1960 Public Use Microdata Sample (PUMS), a 1-in-1000 sample of the records from the 1960 long form. See Todd Gardner, "Steven Ruggles, Census Data Processing, Part 2," U.S. Census Bureau Research Matters Blog, Aug. 2, 2012, accessed at http://researchmatters.blogs.census.gov/2012/ 08/02/steven-ruggles-census-data-processing-part-2/.

${ }^{27}$ SSRC, pp. 21-22. The committee also urged the BoB to place greater emphasis on the systematic preservation of data collected by agencies, ensure sufficient funds were budgeted for that function, evaluate existing data preservation policies, and determine which data should be preserved and how those data could be put into "a more usable form." SSRC, p. 22. The committee further recommended that the government regularly publish an inventory of its machine-readable data. They also offered recommendations for the research community, such as creating an organization to coordinate research requests in order to avoid duplication of requests for data. That organization would also advise the government on making data available and developing integrated data sets. SSRC, p. 29.

${ }^{28}$ Bowman was appointed assistant director for statistical standards in 1955 and remained in that position until his retirement in 1969. Previously, Bowman was the chair of the University of Pennsylvania's department of economics. Duncan and Shelton, pp. 100, 154-156.

${ }^{29}$ Ibid., p. 154. For example, at a 1957 meeting of the Washington, D.C., ASA chapter, Bowman noted: "the statistical program of the United States, although it is recognized as outstanding, nevertheless is not good enough for the demands which are being made on it." Raymond T. Bowman, "Improvement of Federal Statistics," The American Statistician, vol. 11, no. 2 (April 1957), p. 18.
} 
with other records;" in other words, "[r]ecord association is the paramount need." 32 Dunn argued that the problem of data access "does not reside in the assembly of records in a center but in the capacity to provide certain forms of file management and utilization services to the user." 33 In other words, the purpose of the data center would not merely be to warehouse data sets, but to make them compatible with one another so that they could be used by researchers.

Dunn recommended the establishment of a national data center "whose primary mission would be to provide service to users of Federal statistical data both inside and outside the government." 34 The data center would perform the following functions: (1) regulate file storage and management of machine-readable archival records, (2) provide a referral and reference source for users of federal statistics, and (3) perform services to facilitate the use of federal data, such as preparing cross tabulations, matching records as necessary, and performing standard statistical routines. Dunn also noted that data center staff would conduct "[d]isclosure by-passing where technical developments would permit generating processed output in disclosure-free form rather than releasing input data in sensitive form." 35

\subsection{The Kaysen Committee}

The director of the Bureau of the Budget next created a task force to examine options for improving the storage of and access to federal statistics. President Lyndon B. Johnson announced the task force in December 8, 1965, noting, "present methods of storing, indexing and collating [government statistics] do not permit maximum use of these data. With new information technology now available, it is possible to make these systems both more efficient and, at the same time, more useful." ${ }^{36}$ The members of the

\footnotetext{
${ }^{30}$ Duncan and Shelton, p. 176. Dunn, a research associate with Resources for the Future, Inc., had previously served as the Deputy Assistant Secretary for Economic Affairs of the Department of Commerce. The Coordination and Integration of Government Statistical Programs, hearings before the Subcomm. on Economic Statistics of the Joint Economic Comm., $90^{\text {th }}$ Cong., $1^{\text {st }}$ Sess., May 17-18; June $7-8,1967$, p. 4

${ }^{31}$ U.S. Bureau of the Budget, Office of Statistical Standards, Review of Proposal for a National Data Center, Statistical Evaluation Report No. 6, December 1965, reprinted in Edgar S. Dunn, Jr., Socia Information Processing and Statistical Systems - Change and Reform (New York: John Wiley \& Sons, 1974), p. 204.

32 Ibid., p. 218.

${ }^{33}$ Ibid.

${ }^{34}$ Ibid., p. 219.

${ }^{35}$ Ibid. Dunn briefly addressed the "disclosure problem" in his report, noting that policies limiting the release of information were becoming more restrictive. However, he stated, "[i]t is not widely understood that the interest in microdata and the existing pressures and constraints do not grow out of an interest in information about the specific respondent." Ibid., p. 210. In addition, a technical appendix to the report, prepared by the National Bureau of Standards at the request of the BoB, noted that center staff would perform confidentiality audits before releasing data to customers, though "this raises complex and difficult issues which require intensive study;" nonetheless, they were certain those issues could be resolved "with the aid of modern tools of the mathematical and computer sciences." E. Glaser, D. Rosenblatt, and M.K. Wood, National Bureau of Standards, "The Design of a Federal Statistical Center," appendix C in U.S. Bureau of the Budget, Office of Statistical Standards, Review of Proposal for a National Data Center, reprinted in The American Statistician, vol. 21, no. 1 (February 1967), p. 18.
} 
task force were: Carl Kaysen of the Institute of Advanced Study (chairman), Charles C. Holt of the University of Wisconsin, Richard Holton of the University of California at Berkeley, George Kozmetsky of the University of Texas, H. Russell Morrison of the Standard Statistics Co., and Richard Ruggles of Yale University.

In directing the work of the task force, known as the Kaysen Committee, Raymond Bowman noted that when considering the creation of a national data center, the group should consider the following: the data center should have autonomy, but should work in consultation with the statistical agencies, and the center should not be responsible for collecting data directly from the public. Bowman also stated that the data center would "need imaginative and energetic promotion by a director who is free of current bureaucratic ties to any agency..." 37 The committee quickly determined that they needed to view the issue in a broader context, so they decided to study how the federal statistical system could be organized to accomplish the following goals: (1) meeting increasing needs for statistical information, (2) developing safeguards to protect respondents' privacy, (3) making the best use of existing information, and (4) minimizing the reporting burden on individuals and businesses. ${ }^{38}$

In its October 1966 report, the committee recommended a national data center be established to support the coordination and joint storage of federal statistics. It stressed the efficiency and cost-savings of a national data center, noting that it would reduce the collection burden on respondents, increase government efficiency, and reduce the costs of processing and storing data. ${ }^{39}$ Its purpose would be to assemble the data collected by various sources and improve access to the data by making the various data sets compatible with one another and providing work space and computer facilities for researchers.

Specifically, the committee identified eight functions of the data center: (1) establishing and maintaining an inventory of all available government data; (2) setting and enforcing uniform disclosure standards to meet confidentiality requirements; (3) performing similar tasks for data collected by state and local governments; (4) assembling and integrating data from government sources and preserving the data "in usable and accessible form;" (5) setting standards for further data collection efforts, "so as to make maximum use of administrative information and provide maximum cross-linking of different bodies of data;" (6) providing facilities for researchers to access the data; (7) developing hardware and software for integrating and accessing the data; and (8)

\footnotetext{
${ }^{36}$ The White House, press release, Dec. 18, 1965. In a memorandum to the President discussing the need for a task force, the BoB director stated that the federal statistical system had problems with regard to archiving data and providing access to researchers and administrative records "should be used whenever possible instead of imposing additional reporting burden on the public." Charles L. Schultze, director, Bureau of the Budget, Memorandum for President Lyndon B. Johnson, re: Planning for a Federal Data Center, Nov. 3, 1965 (RG 51). Schultze also stated: "A modern Federal Data Center would also increase the effectiveness of planning for the Great Society programs." Ibid.

${ }^{37}$ Raymond T. Bowman, "Statement of R.T. Bowman to the Task Force to advise the Bureau of the Budget on measures which should be taken to improve the storage of and access to U.S. Government Statistics," Jan. 1, 1966 (RG 51).

${ }^{38}$ Report of the Task Force on the Storage of and Access to Government Statistics, October 1966 , p. 11, reprinted in The American Statistician, vol. 23, no. 3 (June 1969), pp. 11-19.
} 
defining regulations and compensation arrangements to permit access to the data by nongovernmental researchers. ${ }^{40}$

The committee acknowledged that the agencies were working on developing an integrated body of federal statistics. In particular, they stated: "[t]he Census has taken a commendable lead and already has done a number of useful tasks." 41 They noted, however, that the Census Bureau and other agencies viewed the task as a second-priority activity, which cannot compete for personnel, machine time, or funds with ongoing programs and that "[s]imple inter-agency jealousies and rivalries have also created inhibitions on prompt and full cooperation." ${ }^{42}$

The Kaysen Committee recommended that a new position, the Director of the Federal Statistical System, be established within the Executive Office of the President. The national data center, the Census Bureau, and the Office of Statistical Standards would report to the Director of the Federal Statistical System. The committee placed the Census Bureau in the new organization because it was "the largest, most widely experienced, most professionally competent, and broadest in scope" of all of the federal statistical agencies and, therefore, would be able to perform the functions required of a centralized statistical organization. ${ }^{43}$ The committee further noted that the national data center would need the cooperation and support of the Census Bureau to function effectively. However, the data center would perform different tasks than the Census Bureau and, therefore, would not be subordinate to that agency. Independence from the Census Bureau would also result in "smooth working relations between the Center and the other elements of the Federal Statistical System." 44

\section{Congress and the Public React}

\subsection{Hearings on a National Data Center}

The reaction of Congress to the national data center concept was swift and strong. The proposal came amid congressional hearings and proposed legislation on various aspects of privacy during the first half of the 1960s, including the use of lie detectors, psychological testing, background investigations of job applicants, and the privacy rights of federal employees. ${ }^{45}$ Particularly concerned with the national data center proposal were the Senate Committee on the Judiciary's Subcommittee on Administrative Practice and Procedure, chaired by Sen. Edward V. Long (D-MO), and Subcommittee on Constitutional Rights, chaired by Sen. Sam J. Ervin, Jr. (D-NC). In addition, the

\footnotetext{
${ }^{39}$ Ibid., pp. $16-17$.

${ }^{40}$ Ibid.

${ }^{41}$ Ibid., p. 14.

${ }^{42}$ Ibid.

${ }^{43}$ Ibid., p. 16.

${ }^{44}$ Ibid., p. 17. Earlier the committee had recommended that the Bureau of Labor Statistics (BLS) be included in the new organization; however Raymond Bowman did not agree and told the BoB director he was "particularly disturbed" with this suggestion because it made "no sense at all to propose a BLS and a Census Bureau in a Central Statistical Organization." Raymond T. Bowman, Memorandum for the Director, July 26, 1966 (RG 51).
} 
House Government Operations Committee, Special Subcommittee on Invasion of Privacy, chaired by Rep. Cornelius E. Gallagher (D-NJ), focused much attention on the national data center.

At the hearings, advocates for the national data center (including Ruggles, Dunn, and Bowman) seemed unable to clearly defend their proposal and appeared largely unconcerned with potential invasions of privacy. For example, in testimony before the Senate Subcommittee on Administrative Practice and Procedure in June 1966, ${ }^{46}$ Edgar Dunn minimized the privacy issue and instead focused on the public good that would be provided by the national data center. ${ }^{47}$ Likewise, at the July 1966 hearings of the House Special Subcommittee on Invasion of Privacy, ${ }^{48}$ data center proponents were unable to explain the difference between their idea of a national data center and the concept for a "total information system" that could be used to compile "dossier" information on individuals. ${ }^{49}$ Witnesses at the hearing included Richard Ruggles, Edgar Dunn, Raymond Bowman, and several authors and scholars of privacy. One witness, author and sociologist Vance Packard, concluded: "My own hunch is that Big Brother, if he ever comes to these United States, may turn out to be not a greedy power seeker, but rather a relentless bureaucrat obsessed with efficiency." 50

After the hearings, Rep. Gallagher reported to the House Operations Committee that although the proposal could improve government efficiency, it also represented a serious threat to privacy. Gallagher was concerned with the amount and types of data that could be stored in such a center, including tax records, census information, credit records, health data, school records, and even police files. Although he acknowledged the BoB's position that the development of personal "dossiers" was not the intent of the proposal, he stated, "our concern is what an innocent statistical center could turn into as the years roll by and pressure mounts to program into the computers more and more information on individuals." ${ }_{11}$ Gallagher concluded that greater efficiency "would be paid for at the far greater expense of weakening the right to privacy of all American

\footnotetext{
${ }^{45}$ See, e.g., William A. Creech, "The Privacy of Government Employees," Law and Contemporary Problems, vol. 31, no. 2 (Spring 1966); Psychological Tests and Constitutional Rights, hearings before the Subcomm. on Constitutional Rights of the Senate Judiciary Comm., $89^{\text {th }}$ Cong., $1^{\text {st }}$ Sess., June $7-$ 10, 1965; Privacy and the Rights of Federal Employees, hearings before the Subcomm. on Constitutional Rights of the Senate Judiciary Comm., $89^{\text {th }}$ Cong., $2^{\text {nd }}$ Sess., October 3-4, 1966; Privacy and the Rights of Federal Employees, hearings before the House Comm. on Post Office and Civil Service, $90^{\text {th }}$ Cong., $2^{\text {nd }}$ ess., June 13, 18, 27; July 2, 9-12, 16-17, 1968.

${ }^{46}$ Invasions of Privacy, hearings before the Subcomm. on Administrative Practice and Procedure of the Senate Comm. on the Judiciary, 89 ${ }^{\text {th }}$ Cong., $2^{\text {nd }}$ Sess. Mar. 23-30, June 7-16. 1966.

${ }^{47}$ Senate Comm. on the Judiciary, Subcomm. on Constitutional Rights, Federal Data Banks and Constitutional Rights: A Study of Data Systems on Individuals Maintained By Agencies of the United States Government, 93 ${ }^{\text {rd }}$ Cong., committee print, 1974, p. 8.

${ }^{48}$ The Computer and Invasion of Privacy, hearings before the Special Subcomm. on Invasion of Privacy, House Comm. on Government Operations, $89^{\text {th }}$ Cong., July 26-28, 1966. The subcommittee members were Rep. Cornelius Gallagher (D-NJ), Rep. Benjamin Rosenthal (D-NY), and Rep. Frank Horton (R-NY).

${ }^{49}$ Julian Nixon, Council of Social Science Data Archives, "Federal Data Centers-Past and Proposed," undated, reprinted in Computer Privacy, hearings before the Subcomm. on Administrative Practice and Procedure of the Senate Comm. on the Judiciary, $90^{\text {th }}$ Cong., $1^{\text {st }}$ Sess., March 14-15, 1967, pp. 199-204.

${ }^{50}$ The Computer and Invasion of Privacy, p. 13 (statement of Vance Packard).
} 
citizens. Surely this is too exorbitant a price to pay for an economized filing system." 52

Gallagher identified five potential threats posed by a national data center: (1) errors in the data, (2) distortions of information caused by technological malfunctions, (3) misuse of the data by persons working with the data, (4) misuse of the data by persons through remote access, and (5) violations of confidentiality rules. ${ }^{53}$ He was also concerned that proponents of the data center had not sufficiently examined the cost effectiveness of the center, and that they had not fully examined whether the center would duplicate ongoing efforts of the individual agencies. ${ }^{54}$ Gallagher stated that the Kaysen committee report and its predecessors "represented an insufficient examination of all the problems and potentialities that would arise from the establishment of a National Data Center." "55 Further, in a letter to the director of the BoB, Gallagher commented on the Kaysen Committee report, calling it superficial and a rehash of the previous studies. He stated: "I believe that the American people deserved something better from the distinguished panel that studied the problem for a period of nearly eleven months at the expense of the American taxpayers..." 56

At first, congressional concern was focused on the impact of technological change on individual privacy. However, concern soon turned to the extent of information on individuals maintained by federal agencies. ${ }^{57}$ In 1966, the Senate Subcommittee on Administrative Practice and Procedure surveyed federal agencies about the amount of personal information they collected. ${ }^{58}$ The study identified more than three billion records on individuals, including names, addresses, criminal histories, mental health records, and financial records. The study concluded that much of the information collected by the government was irrelevant and in some instances, confidentiality provisions were not meaningful or not enforced. ${ }^{59}$

\footnotetext{
${ }^{51}$ Cornelius Gallagher, "Questions of Invasions of Privacy Relating to the Establishment of a National Data Center," 112 Cong. Rec. 19962 (Aug. 18, 1966).

${ }^{52}$ Ibid.

${ }^{53}$ Cornelius Gallagher, "Privacy and the National Data Center," speech before the Joint Computer Conference, Atlantic City, NJ, April 18, 1967, reprinted in 113 Cong. Rec. 29590, Oct. 20, 1967 (entered into the record by Rep. Daniels).

54 "The Federal Data Center and the Invasion of Privacy-A Progress Report," 113 Cong. Rec. 6747 (March 15, 1967) (statement of Rep. Gallagher).

${ }^{55}$ Ibid.

${ }^{56}$ Cornelius Gallagher, letter to Charles L. Schultze, director, Bureau of the Budget, Dec. 1, 1966, p. 1.

${ }^{57}$ Priscilla M. Regan, Legislating Privacy (Chapel Hill, NC: University of North Carolina Press, 1995), pp. $72-74$

${ }^{58}$ Senate Comm. on the Judiciary, Subcomm. on Administrative Practice and Procedure, Government Dossier: Survey of Information Contained in Government Files, $90^{\text {th }}$ Cong., $1^{\text {st }}$ Sess., committee print, 1967.

${ }^{59}$ Ibid., pp. 7-9. Five years later, the Senate Subcommittee on Constitutional Rights launched a four-year study of data banks maintained by federal agencies. The study uncovered 858 data banks containing more than 1.25 billion records on individuals. In addition to the large number, the subcommittee was alarmed by the fact that they "met evasion, delay, inadequate and cavalier responses, and all too often laziness born of a resentment that anyone should be inquiring about their activities. Some agencies displayed their arrogance by not replying at all. With others, extracting information was like pulling teeth." Senate Comm. on the Judiciary, Subcomm. on Constitutional Rights, Federal Data Banks and Constitutional Rights, p. iv (statement of Sen. Sam J. Ervin, Jr., chairman).
} 
The only congressional support for a data center came from the Joint Economic Committee. In its 1967 hearings on the coordination and integration of government statistical programs, the committee examined the efficiency of the federal statistical system and explored the possibility of a national data center, including the implications of such a center and the "problem of disclosure and of safeguarding the rights of individuals to personal privacy." 60 In a companion report, the committee concluded that the information collected by the government did not meet the needs of the nation. They recommended that steps be taken to integrate the federal statistical programs and establish a national statistical center. ${ }^{61}$

Nonetheless, in August 1968, the House Special Subcommittee on Invasion of Privacy strongly recommended that the creation of a national data center be postponed until the technical requirements for protecting privacy could be fully explored. The subcommittee stressed that privacy needed to be a priority when designing the data center, and recommended that if a data center were developed, the data should be kept in aggregate form so that no individuals could be identified. They also recommended that the data center not be placed in an existing federal agency, but in an independent commission. ${ }^{62}$

\subsection{Public Reaction to the National Data Center Proposal}

Extensive media coverage of the hearings revealed far-reaching concerns over the potential invasion of privacy. ${ }^{63}$ In an era of growing distrust of and frustration with government bureaucracy, the media rallied against the national data center proposal. Despite its proposed efficiencies, the national data center proposal stirred up thoughts of loss of privacy, infringement of rights, and even totalitarianism. ${ }^{64}$ While some called for legal checks and balances to be put in place to safeguard information in the national data center, such as the ability for an individual to review the information maintained about him- or herself, others called for its immediate demise. The authors' sentiments were captured succinctly by the headlines, for example:

- "Tyranny of the Statistic," Christian Science Monitor, July 29, 1966

- "Computer Abuse Threatens Privacy," Systems, September 1966

- "Computer as Big Brother," Pittsburgh Post-Gazette, August 1966

\footnotetext{
${ }^{60}$ The Coordination and Integration of Government Statistical Programs, hearings before the Subcomm. on Economic Statistics of the Joint Economic Comm., 90 ${ }^{\text {th }}$ Cong., ${ }^{\text {st }}$ Sess., May 17-18; June $7-8,1967$, p. 2. In his opening remarks, the subcommittee chairman acknowledged, "[t]he statistical needs of the private sector have also become increasingly demanding. Examples include data for business planning and for the large number of individuals engaged in social science research." Ibid., p. 1 (statement of Herman E. Talmadge, Chairman).

${ }^{61}$ Joint Economic Comm., Subcomm. on Economic Statistics, The Coordination and Integration of Government Statistical Programs, $90^{\text {th }}$ Cong., $1^{\text {st }}$ Sess., joint committee report, 1967, p. 9.

${ }^{62}$ Luther J. Carter, "National Data Bank: Its Advocates Try to Erase 'Big Brother' Image," Science, vol. 163, no. 3863 (Jan. 10, 1969), p. 163; Senate Comm. on the Judiciary, Subcomm. on Constitutional Rights, Federal Data Banks and Constitutional Rights, p. 10.
} 
- "Big Brother Never Rests," Indianapolis Star, August 15, 1966

- "A Giant Peeping Tom," Paterson (NJ) Evening News, August 8, 1966

One paper called the national data center concept "the apex of bureaucracy and entirely totalitarian in conception," 65 while another stated that the "evil potential of a centralized electronic card file for Americans is obvious." 66 The editors of the Christian Science Monitor stated that they were "frankly repelled by the proposal," noting that "[i]t would constitute a monstrous invasion of privacy and a threat to the liberties of every American." 67

The Wall Street Journal also noted the threat to civil liberties. The paper called attention to the potential misuse of the data center and called for its rejection:

We do not suggest that many officials would attempt to abuse the power. Yet the fact is that even as it is, Federal agencies have been known to harass individuals or businesses, just as some of them have not been above electronic prying and other violations of privacy.

In any event, it is a cardinal requirement for a free society that the people do not entrust their liberties to the whims of men in power but rely rather on wise laws to protect them from oppression. ...Congress should promptly and emphatically dispatch the Budget Bureau's incipient octopus. ${ }^{68}$

In a similar vein, an editorial in The New York Times stated, "[t]he Orwellian nightmare" would be realized if the national data center were approved. ${ }^{69}$ The editorial went on to say:

We already live with the fact that from birth to grave Federal agencies keep tabs on each of us, recording our individual puny existence, monitoring our incomes and claimed deductions, noting when we are employed or jobless, and - through the F.B.I. and similar agencies - keeping all too close watch on what we think or say, what we read and what organizations we belong to. ...Understandably, this idea has brought vigorous protest, in which we join. ${ }^{70}$

63 "Privacy Subcommittee Brings a Sense of Balance to Technological Growth and the Right To Privacy," 112 Cong. Rec. 28688-28705 (Oct. 21, 1966) (newspaper articles entered into the record by Rep. Gallagher).

${ }^{64}$ See, e.g., "House Panel Opens Hearings on Complex Problems-Will Computer Bank Destroy Privacy?" Houston Post, July 27, 1966, reprinted in 112 Cong. Rec. 28689 (Oct. 21, 1966); "Big Brother Wants You," Arizona Republic, Aug. 7, 1966 reprinted in 112 Cong. Rec. 28694 (Oct. 21, 1966); Erwin Knoll, "Our Fisbowl Society_Prying and Privacy," reprinted in 112 Cong. Rec. 28701 (Oct. 21, 1966).

65 "Computer Abuse Threatens Privacy," Systems, September 1966, reprinted in 112 Cong. Rec. 28691 (Oct. 21, 1966).

66 "Computer as Big Brother," Pittsburgh Post-Gazette, August 1966, reprinted in 112 Cong. Rec. 28692 (Oct. 21, 1966).

67 "Tyranny of the Statistic," Christian Science Monitor, July 29, 1966, reprinted in 112 Cong. Rec. 28691 (Oct. 21, 1966). 
While several journalists admitted there were potential efficiencies of a national data center and no "Big Brother motivations at the outset," ${ }^{71}$ others more emphatically sounded the warning about the potential misuses of the information and future inclusion of harmful information. ${ }^{72}$ One description of the data center forewarned: "[u]ltimately, the computer will be expanded to include the life history of every citizen: his schooling, grades, military service, personality traits, police record, employment, income, credit rating and every other item of information alleged to be pertinent or revealing." 73 Other reporters noted that information contained in government files may not be accurate or true, asserting "F.B.I. files are full of absolutely unsubstantiated accusations, consisting at least partially of mere gossip, against thousands of perfectly good, loyal citizens." ${ }^{74}$

Continuing congressional attention kept the national data center proposal in the news for several years. National magazines, including Look, The Atlantic, Newsweek, U.S. News $\&$ World Report, and even Playboy, continued to cover the issue, as well as general issues related to privacy and advances in computer technology. In November 1967, Arthur Miller wrote in The Atlantic: "a Data Center poses a grave threat to individual freedom and privacy. With its insatiable appetite for information, its inability to forget anything that has been put into it, a central computer might become the heart of a government surveillance system." ${ }^{75}$ The following year, Look carried an article that discussed the numerous data banks already in existence at the time and the lack of regulation over access to the information they contained. The article noted that the ability of federal agencies to match data maintained by other agencies resulted in a de facto data center whether or not one was officially established. ${ }^{76}$

It was not only the media that responded to the national data center proposal. Letters from concerned citizens poured in from around the country expressing concern not only to members of Congress but to the director of Bureau of the Budget and the President, as well. In addition, for example, a nun wrote her representative about the "hazardous project" she referred to as the "Computer dossier data bank."77 Another

\footnotetext{
68 "Review and Outlook-Too Personal by Far," The Wall Street Journal, Aug. 5, 1966, reprinted in 112 Cong. Rec. 28690-28691 (Oct. 21, 1966).

69 "To Preserve Privacy," editorial, The New York Times, Aug. 9, 1966, reprinted in 112 Cong. Rec. 19964 (Aug. 18, 1966).

${ }^{70}$ Ibid.

${ }^{71}$ Edward P. Morgan and the News, July 26, 1966, reprinted in 112 Cong. Rec. 28697 (Oct. 21, 1966).

${ }^{72}$ See, e.g., "National Data Center Has Frightening Implications," Providence (RI) Journal, Aug. 1, 1966, reprinted in 112 Cong. Rec. 28692 (Oct. 21, 1966); "Computer as Big Brother," Pittsburgh Post-Gazette, Aug. 1966, reprinted in 112 Cong. Rec. 28692 (Oct. 21, 1966).

73 "An All-Knowing Computer," Winston-Salem (NC) Journal and Sentinel, July 31, 1966, reprinted in 112 Cong. Rec. 28694 (Oct. 21, 1966).

74 "Centralized Computer Threat to Freedom?" Benton Harbor News-Palladium, Aug. 1, 1966, reprinted in 112 Cong. Rec. 28694 (Oct. 21, 1966). See also "Computer Technology Receiving Its First Investigation in Regard to The Need for Establishing Ethical and Legal Protection as Well as Technological Safeguards for Certain System Applications," Computing Newsline, July 29, 1966, reprinted in 112 Cong. Rec. 28696 (Oct. 21, 1966); Ernest Conine, "A Clear and Future Peril," Los Angeles Times, July 17, 1966, reprinted in 112 Cong. Rec. 28698 (Oct. 21, 1966).

${ }^{75}$ Arthur R. Miller, "The National Data Center and Personal Privacy," The Atlantic, November 1967.

${ }^{76}$ Jack Star, "The Computer Data Bank: Will It Kill Your Freedom?" Look, June 1968.
} 
citizen wrote President Johnson to dismiss the idealistic claims of the supporters of the data center, noting that the center would "place a powerful surveillance instrument in the hands of government officials" and that records that were lost or inaccurate "accidentally could have damaging consequences to the person so affected." 78

In a sermon at the Washington Cathedral on September 19, 1966, Canon Michael Hamilton discussed the moral issues related to a national data center. He noted that even though privacy safeguards could be incorporated into the national data center, "there is no absolute safe system, because evil men may gain control of a mechanism and dismantle those safeguards. Granted that the present intentions of the Government are benign, and that the advantages of such a Center are enormous, what if a tyrant of one kind or another gains power over these files? Is the risk worth taking?" 79 However, Hamilton stated that the nation should cautiously continue it plans for the data center, for not to do so would be to lose faith in ourselves as a nation and in the flexibility of our political system to adapt creatively to change." 80

In a 1967 article on the fourth amendment and privacy, Rabbi Norman Lamm stated that although there was no "technical legal objection to this proposed National Data Center; ...the whole sense of Jewish law and universal morality must reject such a plan as abhorrent." 81 Dr. Lamm recognized that the proponents of the data center were wellintentioned, but noted: "if the mechanism exists, then we may be sure that, by some as yet undiscovered law that issues from the depths of human and social perversity, all kinds of information will be forthcoming in an attempt to satisfy its insatiable appetite for more and more facts, regardless of their relevance, need, or accuracy." 82

The Daughters of the American Revolution (DAR) also addressed the topic. At their annual meeting in 1967, the DAR resolved:

Whereas a proposal for a Federal Data Center is being developed to establish a single machine-age information reservoir on every American citizen... Whereas this information assembled into a complete dossier can become a formidable invasion of personal privacy or even a potential source of blackmail...

Resolved, That the National Society of the Daughters of the American Revolution expose the fallacies and evident dangers to our free society in such a central pooling of information on the citizen's private life and call for the

\footnotetext{
${ }^{77}$ Sister Mary Romana, R.S.M, Rogers City, MI, letter to Rep. Philip E. Ruppe, Jan. 27, 1967 (RG $51)$.

${ }^{78}$ Richard A. Nickey, Elmhurst, IL, letter to President Lyndon B. Johnson, June 19, 1967 (RG 51).

${ }^{79}$ Michael Hamilton, "The Human Use of Technology," Sept. 19, 1966, reprinted in 112 Cong. Rec. 24677-24678 (Sept. 30, 1966) (entered into the record by Sen. Pell). Hamilton noted that the advantages of the national data center were that it would show the interrelationships among federal data sets, relieve "some of the repetitive form filing involved in working with the Government," increase government efficiency, and reduce costs.

${ }^{80}$ Ibid., p. 24678.

${ }^{81}$ Norman Lamm, "The Fourth Amendment and Its Equivalent in the Halachah," Judaism (summer 1967), reprinted in 113 Cong. Rec. 30895-30899 (Nov. 2, 1967) (entered into the record by Sen. Long).

${ }^{82}$ Ibid., p. 30897.
} 
fullest open discussion of the wisdom or necessity for such a Federal data bank. ${ }^{83}$

That same year, another group elevated the issue to an international level. The Commission to Study the Organization of Peace ${ }^{84}$ made recommendations to the United Nations concerning computers and privacy. The commission specifically referred to the national data center proposals and the hearings held by the Gallagher committee and stated that it is "doubly important to consider the advisability of the whole scheme and, in case of its execution, to provide sufficient safeguards with respect to the maximum accuracy of the data, their confidentiality, access to them, and the permissibility of their use in situations involving an invasion of individual privacy." 85

\section{Response to the Controversy}

\subsection{The Research Community Chimes In}

Amidst the privacy controversy, the research community was discussing matters of privacy, confidentiality, and informed consent, often in direct response to the national data center proposal. Researchers agreed having more data was desirable, but were less certain about the existence of any threat to privacy. Several authors discussed the tension between the need for information and the rights of individuals, ${ }^{86}$ though some seemed rather astonished by the concerns over privacy expressed by research subjects. ${ }^{87}$ Others dismissed the public outcry over the data center proposal as fear of the "impersonal nature" of the computer or lack of understanding of technology. ${ }^{88}$ For example, one researcher argued that the 1966 hearings of the Gallagher committee were reported "in a biased and distorted way" and noted that while there were ethical, legal, and technical issues that needed to be resolved, the government could provide less expensive, more efficient services and research could be "more meaningfully pursued" if government data

\footnotetext{
${ }^{83}$ Daughters of the American Revolution, "Resolutions of National Society of DAR," reprinted in 113 Cong. Rec. 15372-15373 (June 12, 1967) (entered into the record by Sen. Thurmond).

${ }^{84}$ The commission was established during World War II by James Shotwell and leaders of the former League of Nations. David Cortright, Peace: A History of Movements and Ideas (Cambridge, United Kingdom: Cambridge University Press, 2008), p. 111; Arthur K. Kuhn, "Editorial Comment: The Organization of Peace," The American Journal of International Law, vol. 35, no. 1 (January 1941), pp. 114-117.

${ }^{85}$ Commission to Study the Organization of Peace, The United Nations and Human Rights, $18^{\text {th }}$ report, reprinted in 113 Cong. Rec. 28319-28320 (Oct. 10, 1967) (entered into the record by Sen. Long).
} 
were available to social scientists. ${ }^{89}$

In 1968, T.J. Vander Noot of the Economic Council of Canada, noted that it was "curious" that the proposed national data center had resulted in a national debate because it did not present new challenges to privacy and confidentiality, it just concentrated the issue "into one large package." 90 He allowed, however, that "perhaps the coupling of disclosure and confidentiality considerations with the arcane mysteries of the computer was bound to stimulate discussion."91 That same year, Herman Miller, chief of the Census Bureau's Population Division, suggested that those who oppose the data center "may be grossly underestimating the importance of statistics as a tool for public policy." 92 Miller also noted that "[i]t would be a mistake to exaggerate the likelihood that census data will be disclosed to unauthorized persons or that they will be used to the detriment of individuals." 93

There were some researchers offering dissenting opinions, however. A former federal government statistician stated that the proposed national data center plan had "many objectionable features" and faulted the Kaysen Committee for failing to address "the particulars" of confidentiality. ${ }^{94}$ Similarly, the director of the National Center for Health Statistics criticized "the tendency of data bank proponents to neglect basic problems of data collection" and accused them of being "wildly optimistic about what is really available." 95 He noted that linking data on individuals from a variety of data sets "raise[d] serious questions of privacy which must be answered." 96 Similarly, Ewan Clague, former commissioner of the Bureau of Labor Statistics, informed Congress of his support for a national data center with "certain cautions and conditions," partic-

\footnotetext{
${ }^{86}$ Chester C. Bennett, "What Price Privacy?" American Psychologist, vol. 22, no. 5 (May 1967), pp. 371-376; Dale Tillery, "Seeking a Balance Between the Right of Privacy and the Advancement of Social Research," Journal of Educational Measurement, vol. 4, no. 1 (Spring 1967), pp. 11-16; Jack Sawyer and Howard Schechter, "Computers, Privacy, and the National Data Center: The Responsibility of Social Scientists," American Psychologist, vol. 23, no. 11 (November 1968), pp. 810-818.

${ }^{87}$ For example, in discussing a study of students, Tillery notes "the extent of the concern of the protection of the individual student and his home was far greater than had been anticipated." Tillery, p. 11 .

${ }^{88}$ Bennett, p. 374

${ }^{89}$ Ralph L. Bisco, "Social Science Data Archives: Progress and Prospects," Social Science Information, vol. 6 (1967), p. 70. Bisco wrote a series of papers describing the technical and functional requirements of data archives, and noted the increased demand for access to data collected by the federal government and the lack of policies, procedures, and standards for the preservation and use of the data. See also Ralph L. Bisco, "Social Science Data Archives: Technical Considerations," Social Science Information, vol. 4 (1965), pp. 129-150; Ralph L. Bisco, "Social Science Data Archives: A Review of Developments," The American Political Science Review, vol. 60, no. 1 (March 1966), pp. 93-109.

${ }^{90}$ T.J. Vander Noot, "Computers, Social Science Statisticians, and the A.S.A.," The American Statistician, vol. 22, no. 3 (June 1968), p. 21. The Economic Council of Canada was established in 1963 and disbanded in 1993. Funded by the government, its purpose was to study economic growth and assess the impact of economic policies. "Economic Council of Canada," The Canadian Encyclopedia, accessed at http://www.thecanadianencyclopedia.com.

${ }^{91}$ Vander Noot, p. 21.

${ }^{92}$ Herman P. Miller, "Processing Census and Sample Survey Data on Social Change and Regional Disparities in the United States," Social Science Information, vol. 7 (1968), p. 130.

${ }^{93}$ Miller, p. 131. To support this argument, Miller cited the fact that "there has not been a single scandal involving the misuse of [census] records." Ibid.
} 
ularly concerning the maintenance of data confidentiality. ${ }^{97}$ Clague added: "I must also express a note of caution against too much optimism as to the usefulness of the raw data to the prospective users. ...It just isn't possible for an outsider without help to make the most effective use of raw data unsupported by experienced and informed interpretation." 98

In 1967, the ASA issued a formal statement concerning the national data center proposal. They favored a slower, more thoughtful approach to developing the data center. In a letter to the director of the $\mathrm{BoB}$, the organization stated it supported the proposal in principle, but cautioned that the Kaysen Committee's recommendations went "too far, too fast." 99 In its letter, the ASA recognized the public's concern about privacy and recommended that the government take steps to ensure confidential data were safeguarded.

\subsection{Proposal Proponents Respond}

After the June 1966 congressional hearings, Edgar Dunn summarized his experiences in a memorandum to the assistant director of the Bureau of the Budget, Charles Zwick, and Carl Kaysen. He mentioned the "flair-up of concern and controversy surrounding the general notion of a data center" and stated that he did not have "the foggiest idea what kicked it off." ${ }^{100}$ Later that year, Kaysen noted that Gallagher's criticisms were

\footnotetext{
${ }^{94}$ A.C. Rosander, "Analysis of the Kaysen Committee Report," The American Statistician, vol. 24, no. 1 (February 1970), pp. 22-25. Rosander worked for BLS, the War Production Board, the IRS, and the Interstate Commerce Commission. He also argued that cost reductions and efficiencies projected by the Kaysen Committee were unsubstantiated and that the report lacked sufficient detail on costs, staffing, and expertise required by the data center.

${ }^{95}$ Theodore D. Woolsey, "Data Banks Are Not the Answer: A Statistician's Viewpoint," American Journal of Public Health, vol. 60, no. 10 (Oct. 1970), pp. 1991, 1994. Woolsey stated he would not take a position on the privacy controversy in his paper, although noted that a data bank would be unfair in that not everyone would have access to it or know that the data existed. He argued that providing data to the public in published form "so that everyone has equal and simultaneous access to it" was more equitable and more efficient. Ibid., pp. 1992-1993.

${ }^{96}$ Woolsey, p. 1993, note.

${ }^{97}$ The Coordination and Integration of Government Statistical Programs, hearings before the Subcomm. on Economic Statistics of the Joint Economic Comm., $90^{\text {th }}$ Cong., ${ }^{\text {st }}$ Sess., May 17-18; June 7-8, 1967, p. 140 (statement of Ewan Clague).

${ }^{98}$ Ibid., p. 136 (statement of Ewan Clague). At the hearings, Frederick F. Stephan, social statistics professor, Princeton University, also urged caution, noting that several studies had argued against concentrating statistical functions into a central agency: "the proposal of a national data center would not appear to be wise if it is to be a consolidation of statistical functions that can be done effectively by the separate agencies engaged in the production of statistical data." Ibid., p. 53 (statement of Frederick F. Stephan). He stated that there has not been enough study of "precisely what types of information would be consolidated in such a center" and that it could become such a large of collection of data "that Congress would be unwilling to pay the cost of collecting it, let alone processing it." Ibid., p. 61. Stephan recommended careful study, cost-benefit analyses, and experimentation be conducted in order to determine the most appropriate form of interagency sharing of data.

${ }^{99}$ Quoted in T.A. Bancroft, "The Statistical Community and the Protection of Privacy," The American Statistician, vol. 26, no. 4 (October 1972), pp. 13-14.
} 
"really pretty annoying." 101

Nonetheless, the authors of the three original data center proposals responded publicly (or at least to their peers) to criticisms that their proposals lacked attention to privacy issues. Dunn agreed that his scant discussion of privacy was "a gigantic oversight." ${ }^{102}$ He defended this oversight, however, in a 1967 article in The American Statistician noting that his report for the BoB was addressed to members of the federal statistical system and, thus, "it was assumed that the protection of personal privacy was a given condition that was understood by everyone concerned." 103 In his article, he reiterated the importance of a national data center, stating: "We are engaged in discussing a public issue that is of the greatest importance to the future of our society. The emerging prospects of better and more useful information systems hold great promise for human welfare" (emphasis added) ${ }^{104}$ Dunn further stated that "[i]t is unnecessary and unfortunate if we identify the prospects for more rational utilization of existing statistical resources with this personal privacy issue in the short-run." 105

In an article in The Public Interest in 1967, Carl Kaysen said that the members of his committee "were moved by professional concern for the quality and usability of the enormous body of government data to take on what they thought to be a necessary, important, and totally unglamorous task. They certainly did not expect it to be controversial." ${ }^{106}$ Kaysen concluded his article by stating that "the risky potentials which might be inherent in a data center are sufficiently unlikely to materialize so that they are outweighed, on balance, by the real improvement in understanding of our economic and social processes this enterprise would make possible, with all the concomitant gains

\footnotetext{
${ }^{100}$ Edgar Dunn, Memorandum to Charlie Zwick and Carl Kazen (sic), re: The National Data Service Center and the Personal Privacy "Flap," June 16, 1966 (RG 51).

${ }^{101}$ Carl Kaysen, letter to Charles J. Zwick, assistant director, Bureau of the Budget, Dec. 6, 1966 (RG 51). Kaysen had written an earlier note to Zwick about the appendix on privacy and confidentiality he added to the committee's report, cautioning that the appendix may need to be toned down because he "kind of got mad at Gallagher." Carl Kaysen, note to Charles J. Zwick, assistant director, Bureau of the Budget, Oct. 21, 1966 (RG 51). In the appendix, the Kaysen Committee referred to the Census Bureau's Title 13 protections and placed the responsibility for privacy with Congress: "the problem of the threat to privacy can be met best by congressional action, which defines a general statutory standard governing the disclosure of information that is collected on individuals..." Report of the Task Force on the Storage of and Access to Government Statistics, October 1966, Annex, p. 18, reprinted in The American Statistician, vol. 23, no. 3 (June 1969), pp. 11-19. The committee also noted they did not intend for the data bank to create "dossiers" of personal information and that it was "clearly within the power of Congress" to differentiate between socioeconomic data and "the sort of personal history information on named individuals that is contained in a personnel file or police file." Ibid., p. 19.

${ }^{102}$ Edgar S. Dunn, "The Idea of a National Data Center and the Issue of Personal Privacy," The American Statistician, vol. 21, no. 1 (February 1967), p. 23.

${ }^{103}$ Dunn, p. 23. Dunn added that he thought this assumption was justified because "legal and procedural protections against revealing information about individuals have been a very basic part of the operation of the Federal statistical programs for many many years! Furthermore, these protections have been phenomenally successful! ...No successful statistical program could exist without full confidence that personal privacy was secured!" Ibid.

${ }^{104}$ Ibid., p. 27.

${ }^{105}$ Ibid.
} 
in intelligent and effective public policy that such understanding could lead to." ${ }^{107}$

At the 1967 hearings of the Subcommittee on Economics Statistics of the Joint Economic Committee of Congress, Dunn and Ruggles tried to dismiss the fears of invasion of privacy. Dunn noted that the concern with privacy had been "misplaced." 108 Making the distinction between intelligence systems and statistical systems, Dr. Dunn noted that the latter produces aggregate - not individual - information. He further testified that "there will be much less temptation to pervert a statistical system for intelligence purposes than is commonly supposed." 109 Similarly, Richard Ruggles, noted that there is "more a fear of possible misuse of information than an objection to its existence" and that "[a]lthough the emphasis in the privacy hearings was mainly on the possible danger of centralizing records, they also brought out that in some instances the centralization of files can result in increasing the protection of individual privacy in situations where there have been flagrant abuses." 110

\subsection{The Bureau of the Budget Regroups}

In February 1967, the director of the BoB, Charles L. Schultze, met with Rep. Cornelius Gallagher concerning the national data center proposal. Schultze agreed that the data center, if approved, would house only statistical summaries and sample data. ${ }^{111} \mathrm{~A}$ few months later at the Joint Economic Committee hearings, Raymond Bowman repeated that the purpose of the data center would be "making our body of data really serve analytical issues" 112 and informed the committee "[t]he way we are thinking about it now is that a data center could be organized within one of the existing agencies of the Federal Government, that such a center should clearly not have in it information whose main use is with respect to individuals." 113 Bowman further stated that "no universe data" would be put into the data center. Only sample data would be included so that the data center would not contain information on all of the individuals and businesses in the United States. ${ }^{114}$ He also noted that he expected that Congress would put into place statutory safeguards, such as the Census Bureau's Title 13 confidentiality provisions. ${ }^{115}$

\footnotetext{
${ }^{106}$ Carl Kaysen, "Data Banks and Dossiers," The Public Interest, Spring 1967, reprinted in Computer Privacy, hearings before the Subcomm. on Administrative Practice and Procedure of the Senate Comm. on the Judiciary, 90 ${ }^{\text {th }}$ Cong., $1^{\text {st }}$ Sess., March 14-15, 1967, pp. 265-269.

${ }^{107}$ Ibid., p. 269

108 The Coordination and Integration of Government Statistical Programs, hearings before the Subcomm. on Economic Statistics of the Joint Economic Comm., 90 ${ }^{\text {th }}$ Cong., $1^{\text {st }}$ Sess., May 17-18; June 7-8, 1967, p. 10 (statement of Edgar S. Dunn). These hearings examined the efficiency of the federal statistical system and explored the possibility of a "National Statistical Center." As mentioned above, the committee generally supported the data center.

${ }^{109}$ Ibid.

${ }^{110}$ Ibid., p. 27 (statement of Richard Ruggles).

${ }^{111}$ Nan Robertson, "Data Bank: A Threat to Your Privacy," The New York Times, Jan. 7, 1968, reprinted in 114 Cong. Rec. 25200 (submitted to the record by Rep. Gallagher).

112 The Coordination and Integration of Government Statistical Programs, p. 74 (statement of Raymond T. Bowman).

${ }^{113}$ Ibid., p. 75 (statement of Raymond T. Bowman).

${ }^{114}$ Ibid.

${ }^{115}$ Similarly, in an address to the American Bar Association, Charles Zwick, assistant BoB director, defended the data center and emphasized that the center would not: be a collection agency, have
} 
In July 1967, the BoB organized the "Task Force on Selection of Statistical Series with Recognized Interrelated Uses for Central Storage (or Access), Collation Procedures and Retrieval Programming" and asked it to identify the hundred most important statistical series maintained by federal agencies. ${ }^{116}$ The following month, BoB director Charles Schultze formally tasked assistant director Zwick with developing a detailed technical plan for developing the data center. Schultze also asked Zwick to evaluate whether the BoB should also propose the consolidation of the Census Bureau with the Bureau of Labor Statistics (BLS), noting that such a consolidation would probably not be advisable since it would be "a good means of killing the data center." 117 The request to study the proposal to consolidate the Census Bureau and BLS was made by Joseph Califano, special assistant to President Johnson. ${ }^{118}$

In late 1967, Bowman began drafting legislation concerning the national data center. Although he agreed privacy safeguards should be built into the data center's computer system and legislation, he admitted that he was unsure how to do so. ${ }^{119}$ The draft "Federal Statistical Service Center Act" was never introduced in Congress. The bill would have placed the data center within the Department of Commerce essentially with the same responsibilities identified by the various data center proposals, including assembling and preserving data in a form that made it accessible for future use, making data available to outside researchers (with no identifiable information), and maintaining an index of data collected by government agencies. In addition the data center would analyze the data collected by various agencies and recommend means of improving the

data on all individuals or firms, or include information from investigatory files. Zwick reminded his audience of the now revised functions of the data center: (1) maintaining an inventory of data collected by the federal government; (2) maintaining information on only a sample of individuals and firms; (3) performing statistical analyses; and (4) providing summary information and results of statistical analyses. Charles J. Zwick, "A National Data Center," presentation before the annual meeting of the American Bar Association, Honolulu, HI, Aug. 8, 1967, p. 4, cited by Robert L. Chartrand and Louise Giovane Becker, "The Federal Data Center: Proposals and Reactions," U.S. Library of Congress, Legislative Reference Service, reprinted in 114 Cong. Rec. 13285-13289 (submitted to the record by Rep. Donald Rumsfeld).

${ }^{116}$ David Rosenblatt, National Bureau of Standards, Memorandum to H.R.J. Grosch, director, Center for Computer Sciences and Technology, July 26, 1967 (RG 51); Raymond T. Bowman, Assistant Director for Statistical Standards, Memorandum for David Rosenblatt, Bureau of Standards; Ezra Glaser, National Institutes of Health; Vito Natrella, IRS; Leon Greenberg, BLS; Joseph Steinberg, SSA; Morris R. Goldman, OBE; and George Sadowsky, Brookings, re: Task Force on Selection of Statistical Series With Recognized Interrelated Uses for Central Storage (or Access), Collation Procedures and Retrieval Programming, July 11, 1967 (RG 51). Task force members were mainly government statisticians, including Joseph Daly, chief mathematical and statistical advisor of the U.S. Census Bureau.

${ }^{117}$ Charles L. Schultze, director, Bureau of the Budget, Memorandum for Charles J. Zwick, assistant director, Bureau of the Budget, Aug. 17, 1967 (RG 51). Zwick's report noted that the merger "would draw attention away from the more important more basic need to improve statistical coordination" and "might jeopardize the establishment of a National Statistical Data Center." Charles J. Zwick, Staff Memorandum, re: Proposed Reorganization of the Bureau of Labor Statistics with the Bureau of the Census, undated (ca. 1967) (RG 51).

${ }^{118}$ Joseph A. Califano, Jr., special assistant to the President, Memorandum for Charles L. Schultze, director, Bureau of the Budget, Aug. 14, 1967 (RG 51). Califano asked Schultze to conduct a staff study "concerning the consolidation of related functions now split between the Departments of Commerce and Labor." 
economy and efficiency of data collection. ${ }^{120}$

By the spring of 1968, plans for the data center were still developing, though slowly. Charles Zwick, now the director of the BoB, reported to Rep. Gallagher that his agency would prepare a "specific, concrete plan" that would be vetted by a variety of stakeholders and assured the Congressman that "[o]nly after that would we consider we had a "proposal' for appropriate consideration by Congress." ${ }^{121}$ Zwick further noted that, given other priorities of the Budget Bureau, he doubted that the proposal would be completed soon. Gallagher considered this "postponement" of the national data center a victory, stating: "I am frankly delighted that a National Data Bank will not soon be added to forces already at work in America which tend to inhibit personal dignity and individual freedom." 122

In 1970, the Bureau of the Budget was reorganized into the Office of Management and Budget (OMB). ${ }^{123}$ Charles Zwick (who had replaced Charles Schultze as director of the BoB in January 1968), was succeeded by President Richard M. Nixon's appointees, Robert Mayo, who served as director from January 1969 to June 1970, and George Schultz, director from July 1970 to June 1972. In 1969, Julius Shiskin was named assistant director for Statistical Policy, a position similar to the one held by Bowman who had retired earlier that year. By 1970, OMB was no longer working on plans for a national data center. ${ }^{124}$

\section{The Census Bureau's Involvement and Ongoing Work}

Despite playing a central role in the Kaysen Committee's recommendations, the Census Bureau itself did not become actively involved in the national data center debate. Nonetheless, in the era of government mistrust and concern over privacy, the 1970 census became entangled in the issue. The Census Bureau, however, continued to perform its regular functions as congressional inquiries and public accusations loomed.

\footnotetext{
${ }^{119}$ Nan Robertson, "Data Bank: A Threat to Your Privacy," The New York Times, Jan. 7, 1968, reprinted in 114 Cong. Rec. 25200 (submitted to the record by Rep. Gallagher).

${ }^{120}$ Paul F. Krueger, assistant chief, Office of Statistical Standards, Bureau of the Budget, Memorandum to Raymond T. Bowman, chief, Office of Statistical Standards, re: Proposal to Establish a Federal Statistical Service Center, May 16, 1968 (RG 51). A copy of the draft legislation was attached to the memorandum.

${ }^{121}$ Quoted in "Budget Bureau Puts Off Data Bank, Gallagher Reveals," Government Employees' Exchange, reprinted in 114 Cong. Rec. 25201 (Aug. 2, 1968) (submitted to the record by Rep. Gallagher).

${ }^{122}$ Ibid.

${ }^{123}$ The White House, Executive Order 1151, "Prescribing the Duties of the Office of Management and Budget and the Domestic Council in the Executive Office of the President," July 1, 1970, 35 F.R. 128 (July 2, 1970).

${ }^{124}$ Arnold R. Weber, Office of Management and Budget, Draft Memorandum to the Director, re: Background on Proposal for a National Data Center, Oct. 22, 1970, p. 4 (RG 51). See also Julius Shiskin, assistant director for statistical policy, Office of Management and Budget, letter to Hon. Philip A. Hart, U.S. Senate, May 4, 1970 (RG 51). Shiskin's letter was in response to a letter Hart had received from a constituent concerning the status of government data banks. Robert E. Marrone, letter to Sen. Philip A. Hart, Jan. 6, 1970 (RG 51).
} 
The Bureau of the Budget and its consultants considered placing the proposed federal data center in the Census Bureau. Although most felt that the center should be independent from existing statistical agencies, placing it in the Census Bureau was considered a logical compromise. ${ }^{125}$ However, an interagency task force assembled at the request of the President to discuss the feasibility of the Kaysen committee proposal could not agree on where the data center should reside organizationally; some members opposed placing the center in the Census Bureau. ${ }^{126}$ John T. Connor, the Secretary of Commerce at the time, supported the suggestion that the data center be placed within the Department of Commerce, although he did not specifically mention placing it in the Census Bureau. ${ }^{127}$

However, the Census Bureau itself does not seem to have been greatly involved in these discussions. When asked if he favored the establishment of a national bank at hearings in 1967, the director of the Census Bureau, Ross Eckler, responded that it was not a matter on which he should have an opinion, noting that it was an issue for the executive branch to decide. He did, however, say that there would be long-run benefits from the development of a data center, as well as legal issues. Eckler also stated: "I would hope that the provisions for the safeguarding of individual data would be at least as rigorous as those we ourselves have." 128

Although the Census Bureau made no official statement for or against the national data center, it did comment on the methodological and confidentiality implications of a such a center. In 1965, Eckler responded to a request from the BoB to review suggestions for improving federal statistics on economic growth that had been submitted to the Joint Economic Committee by social scientists and statisticians. ${ }^{129}$ Eckler recommended a

\footnotetext{
${ }^{125}$ See Edgar Dunn, Memorandum to Raymond T. Bowman, re: Progress Report on Assignment, June 8, 1965 (RG 51); Milton Moss, Memorandum to Mssrs. Krueger and Bowman, re: Federal Data Center-Notes, July 19, 1965 (RG 51); Raymond T. Bowman, Memorandum for the Director, re: Kaysen Draft Report on National Data Center, March 9, 1966 (RG 51). When asked at the July 1966 Gallagher committee hearings where the data center would be located, Bowman responded that it could be in the Census Bureau, the Department of Commerce, or another agency. The Computer and Invasion of Privacy, hearings before the Special Subcomm. on Invasion of Privacy, House Comm. on Government Operations, $89^{\text {th }}$ Cong., July 26-28, 1966, p. 67 (statement of Raymond T. Bowman).

126 "Report of Task Group on Government Organization for Collection and Analysis of Statistics," Nov. 23, 1966. See also Charles L. Schultze, director, Bureau of the Budget, Memorandum for Joseph A. Califano, Jr., special assistant to the President, re: Organization of Economic Statistics, Dec. 16, 1966 (RG 51). This memorandum confirms the President's request that Schultze head up the in-house task force. Attached to this memorandum was a list of potential task force members: Bill Shaw and Ross Eckler, Department of Commerce; William H. Smith, Internal Revenue Service; Winn Finner, Department of Agriculture; Art Ross, Department of Labor; Art Okun, Council of Economic Advisors. It is unclear if the Census Bureaus Ross Eckler had any involvement in the task force.

${ }^{127}$ John T. Connor, secretary, U.S. Department of Commerce, Memorandum to Hon. Joseph A. Califano, Jr., special assistant to the President, re: Reorganization Proposals, Jan. 28, 1966 (RG 51); John T. Connor, secretary, U.S. Department of Commerce, letter to Charles L. Schultze, director, Bureau of the Budget, Dec. 22, 1966 (RG 51). Connor attached an opinion from the general counsel stating that a legislative proposal would not be necessary to place the data center in the Department of Commerce. Robert E. Giles, general counsel, U.S. Department of Commerce, Memorandum to Secretary Connor, re: Legal Review of Proposed "Federal Statistical Data Center," Dec. 22, 1966 (RG $51)$.

${ }^{128}$ Computer Privacy, hearings before the Subcomm. on Administrative Practice and Procedure of the Senate Comm. on the Judiciary, 90 ${ }^{\text {th }}$ Cong., $1^{\text {st }}$ Sess., March $14-15,1967$, p. 111.
} 
cautious approach to establishing a national data center, noting that such a center:

[a]ssumes that the concepts of information, classification, and indexing have been developed to the point at which it is possible to apply them to general statistical material and implement automated systems for handling the receipt, classification, storage, searching and abstracting, retrieval, and dissemination of such data. Although effective systems have been developed in very restricted environments (as to content or as to function), we believe that a great deal of definitional and developmental research and experimentation will need to be done before a cost-effective general-purpose data storage and retrieval system is a practical concept. ${ }^{130}$

The Census Advisory Committee of the American Economic Association discussed the Kaysen Committee's recommendations at its meeting with the Census Bureau in January 1967. The Census Bureau noted that, given the condition of data records and the state of computer technology, matching of most government statistical records would not be possible and matching other records would be very costly. ${ }^{131}$ The advisory committee acknowledged the technical considerations, but recommended that work continue on making government statistics more comparable.

In fact, the Census Bureau indicated that it already did much of what the Kaysen Committee recommended. ${ }^{132}$ In January 1966, Eckler summarized the data center issue in a letter to Andrew Brimmer, the assistant secretary for economic affairs for the Department of Commerce. Eckler said he supported the objectives of the Kaysen Committee, ${ }^{133}$ but emphasized that the Census Bureau was already working on similar projects. Eckler said the Census Bureau "should intensify its efforts to develop workable

\footnotetext{
${ }^{129}$ Joint Economic Committee, Subcomm. on Economic Statistics, Improved Statistics for Economic Growth; comments by government agencies on views submitted to the Subcommittee on Economic Statistics, March 1966. The BoB compiled comments by the agencies. In his transmittal letter to Sen. Proxmire, the chairman of the Subcommittee on Economic Statistics, Raymond Bowman expressed his concerns about the federal statistical system, stating that the overarching theme of the suggestions was the "recognition, implicitly or explicitly, of the need to improve the organization of statistical data so that it can be more effectively used in analysis and policy." Raymond T. Bowman, Executive Office of the President, Bureau of the Budget, letter to Hon. William Proxmire, Chairman, Subcommittee on Economic Statistics, Joint Economic Committee, U.S. Senate, dated Dec. 8, 1965, reprinted in Improved Statistics for Economic Growth, p. 3. Bowman also emphasized the need for a national statistical data center as well as other improvements to federal statistical programs.

${ }^{130}$ A. Ross Eckler, director, Bureau of the Census, letter to Raymond T. Bowman, assistant director for statistical standards, Bureau of the Budget, Oct. 19, 1965, reprinted in Improved Statistics for Economic Growth, p. 35. Other agencies responding to Bowman's request were: the Bureau of Labor Statistics, Internal Revenue Service, Department of Agriculture, Office of Business Economics of the Department of Commerce, National Center for Health Statistics, Office of Education of the Department of Health, Education, and Welfare, and the Federal Reserve System. The only other comment on data sharing was from the Council of Economic Advisors which strongly supported efforts to coordinate statistical programs including "the coding and storing of data in a manner that facilitates the combined use of a range of statistical series in projects requiring their comparability." Arthur M. Okun, member, Council of Economic Advisors, Executive Office of the President, letter to Raymond T. Bowman, assistant director for statistical standards, Bureau of the Budget, Nov. 2, 1965, reprinted in Improved Statistics for Economic Growth, pp. 79-81.
} 
programs for the compilation of general-purpose statistics from the raw data collected for administrative purposes by other agencies." 134

As inquiry into the national data center proposal continued, the day-to-day work of the agency continued. Indeed, much of the ongoing work of the agency was similar to the goals of the national data center; matching data sets and using administrative records was nothing new to the Census Bureau. Between 1967 and 1973, the Census Bureau and state agencies formalized the Federal-State Cooperative Program for Local Population Estimates, which allows the Census Bureau to combine census and administrative records information to produce current population estimates consistent with the last decennial census counts. ${ }^{135}$

In fact, the agency first used administrative records to compile statistics for the 1954 Census of Business. The Census Bureau derived information on selected data items, such as employment, payroll, and sales, for certain nonretail employers from 1954 income tax returns. ${ }^{136}$ The agency also used administrative records from the Internal Revenue Service and Social Security Administration to evaluate the accuracy of the income data collected in the 1950 census. Since then, the Census Bureau used administrative records to study error and bias in census records, and to help compile address lists, improve coverage of hard to count groups, and check the accuracy of the census. ${ }^{137}$ The Census Bureau used administrative records in the 1982 economic and agriculture censuses to obtain data on small businesses, saving close to $\$ 70$ million by not mailing out four million questionnaires to obtain the information and eliminating the collection burden

\footnotetext{
${ }^{131}$ Solomon Fabricant, "Report of the Census Advisory Committee," American Economic Review, vol. 58, no. 2 (May 1968), p. 731.

${ }^{132}$ A later review of the Kaysen Committee's report even noted that the committee's recommendations were "simply a relabeling of the status quo at that time." Joseph W. Duncan and Theodore Clemence, "Arguments for and Against a Decentralized Federal Statistical System," Statistical Reporter, December 1981, pp. 53-61.

${ }^{133}$ In announcing the appointment of the Kaysen committee, the White House noted that to make more effective use of government data the following areas needed improvement: users should be able to get convenient access to publicly available but unpublished data; standards should be established to govern what data should be kept, in what form, and for how long; and standard data sets should be produced to meet major needs, stored on tape, and available to fill special data requests. Quoted in A. Ross Eckler, director, Bureau of the Census, letter to Dr. Andrew F. Brimmer, assistant secretary for economic affairs, U.S. Department of Commerce, Jan. 4, 1966.

${ }^{134}$ Ibid. Similarly, a draft statement prepared for Eckler to give to Congress in 1966 observed that the Census Bureau was already accomplishing the objectives of the Kaysen committee, "with the full protection of the confidentiality of the information." U.S. Census Bureau, "Notes for Director on Data Center and Invasion of Privacy," draft, Aug. 9, 1966, p. 5. The portions of the draft document pertaining to the national data center proposal ultimately were not included in the final draft of the testimony. Eckler appeared before the Subcommittee on Census and Statistics of the House Committee on Post Office and Civil Service in August 1966.
} 
on those businesses. ${ }^{138}$

By the 1980s, the Census Bureau was investigating the use of administrative records to conduct the decennial census. An internal working group, however, concluded that there were serious issues related to coverage and geocoding, and that basic demographic information, such as age, race, and sex, would be difficult to obtain for all persons. ${ }^{139}$ Similarly, in 1992 the General Accounting Office (GAO) $)^{140}$ concluded that conducting an administrative records-based census "would need to overcome a variety of formidable technical, policy, and legal obstacles, such as identifying and securing access to administrative records that contain data collected in the census and matching administrative record sets to each other." 141 Thus, GAO concluded that it saw "no reason to believe that a census that relies fully or even primarily on administrative records for the enumeration is viable for 2000." 142 GAO recommended, however, that the Census Bureau continue to consider the use of administrative records.

\section{Outcomes}

Debate over the 1965 proposal for a national data center led to public concern over the existence of data banks and the lack of privacy safeguards and standards. ${ }^{143}$ These concerns, in turn, resulted in increased scrutiny over the questions asked in the 1970 census and focused attention on other data banks. As Congress and the public viewed data

\footnotetext{
${ }^{135}$ Under this program, federal agencies provide tax records, Medicare records, and some vital statistics information, and state agencies supply vital statistics and information about group quarters such as college dorms or prisons. U.S. Census Bureau, "FSCPE Overview," accessed at http://www.census.gov/population/www/coop/history.html.

${ }^{136}$ Charles G. Langham, U.S. Census Bureau, Economic Censuses of the United States: Historical Development, Working Paper 38, June 1973, p. 15, accessed at http://www.census.gov/history/pdf/ wrkpaper38.pdt.

${ }^{137}$ The Census Bureau has matched samples of census records to IRS and Medicare data as well as birth, death, and employment records. Joseph J. Knott, Bureau of the Census, "Major Administrative Record Files: Documentation and Potential Uses," Proceedings of the Survey Research Methods Section, American Statistical Association, 1979, pp. 67-72, accessed at http://www.amstat.org/sections/ SRMS/Proceedings/papers/1979_008.pdf.; Edwin D. Goldfield, "Innovations in the Decennial Census of Population and Housing: 1940-1990," paper commissioned for the Year 2000 Census Panel Studies, Committee on National Statistics, National Research Council, August 1992, p. 60.

${ }^{138}$ Charles A. Waite, U.S. Census Bureau, "The Future of Administrative Records in the Economic Programs of the Census Bureau," Proceedings of the Survey Research Methods Section, American Statistical Association, 1984, pp. 78-79, accessed at http://www.amstat.org/sections/SRMS/proceedings/ papers/1984_016.pdf.

${ }^{139}$ Thomas B. Jabine, National Academy of Sciences, and Fritz Scheuren, Internal Revenue Service, "Goals for Statistical Uses of Administrative Records: The Next Ten Years," Proceedings of the Survey Research Methods Section, American Statistical Association, 1984, pp. 66-75, accessed at http://www . amstat.org/sections/SRMS/proceedings/papers/1984_014.pdf.

${ }^{140}$ The General Accounting Office officially became the Government Accountability Office on July 7, 2004, pursuant to the GAO Human Capital Reform Act of 2004 (Pub. L. 108-271, 118 Stat. 811 (2004))

${ }^{141}$ L. Nye Stevens, director, Planning and Reporting, General Government Division, U.S. General Accounting Office, "Census Reform: Major Expansion in Use of Administrative Records for 2000 is Doubtful," GAO/T-GGD-92-54, June 26, 1992, p. 1.

${ }^{142}$ Ibid., p. 6 .
} 
banks with increasing suspicion, the government established several panels to evaluate privacy issues. Ultimately, this attention culminated in the passage of the Privacy Act of 1974. However, debate over a centralized or decentralized federal statistical system continued in the decades to follow. These outcomes are discussed below.

\subsection{Increased Scrutiny of the 1970 Census}

As Congress continued to study the related issues of data banks, computers, and privacy, ${ }^{144}$ it also focused its attention on the work of the Census Bureau. In 1968, a brief article in The American Statistician noted that congressional concern about privacy "has led to the introduction of a number of bills designed to limit drastically the Census Bureau's power to require individuals and enterprises to provide information for the Censuses of Population and Housing and the Census of Agriculture." ${ }^{145}$ Congressman Jackson Betts (R-OH) introduced the first such bill in 1967. Betts proposed limiting the number of mandatory questions on the census to seven: name and address, relation to head of household, sex, date of birth, race or color, marital status, and visitors in the home at the time of the census. Additional questions would be permitted, as long as they were not mandatory. ${ }^{146}$ Overall, 44 similar bills were introduced in the $90^{\text {th }}$ Congress (1967-1968) and 70 such bills were introduced in the $91^{\text {st }}$ Congress (1969-1970). Congress took no action on any of these bills. ${ }^{147}$

\footnotetext{
${ }^{143}$ For example, as mentioned above, in 1971, the Subcommittee on Constitutional Rights of the Senate Judiciary Committee launched a four-year study of government data banks. U.S. Senate, Comm. on the Judiciary, Subcomm. on Constitutional Rights, Federal Data Banks and Constitutional Rights: A Study of Data Systems on Individuals Maintained by Agencies of the United States Government, $93^{\text {rd }}$ Congress, $2^{\text {nd }}$ Sess., 1974. See Priscilla M. Regan, Legislating Privacy (Chapel Hill, NC: The University of North Carolina Press, 1995), pp. 72-74.

${ }^{144}$ See Computer Privacy, hearings before the Subcomm. on Administrative Practice and Procedure of the Senate Judiciary Comm., $90^{\text {th }}$ Cong., $1^{\text {st }}$ and $2^{\text {nd }}$ Sess., Mar. 14-15, 1967, Feb. 6, 1968; Federal Data Banks, Computers and the Bill of Rights, hearings before the Subcomm. on Constitutional Rights of the Senate Judiciary Comm., $92^{\text {nd }}$ Cong., $1^{\text {st }}$ Sess., Feb. 23-25; Mar. 2-4, 9-11, 15, 17, 1971; Federal Data Banks and Constitutional Rights, hearings before the Subcomm. on Constitutional Rights of the Senate Comm. on the Judiciary, 93 ${ }^{\text {rd }}$ Congress, $2^{\text {nd }}$ Sess., 1974.

145 "Census Programs Attacked as Invasions of Privacy," The American Statistician, vol. 22, no. 2 (April 1968), p. 12. See John Kanter, "The Census Under Attack," The American Sociologist, vol. 4, no. 3 (August 1969), p. 256.

${ }^{146}$ Ibid. See H.R. 10952 (June 1967); Hearings on H.R. 10952, House Comm. on Post Office and Civil Service, $90^{\text {th }}$ Cong., $1^{\text {st }}$ Sess. (1967). Interestingly, this proposal was not supported by Rep. Cornelius Gallagher, the chairman of the House Special Subcommittee on Invasion of Privacy, who stated: "Any voluntariness of census would render all information subject to the vagaries of any poll." Quoted in "Census Programs Attacked as Invasions of Privacy," The American Statistician, p. 13. Gallagher did note, however, that the more important question was "what happens to that information after it is collected." Ibid.

${ }^{147}$ Curiously, just a few years earlier, some members of Congress had been calling for more census data. For example, hearings were held in 1961 concerning the usefulness of a mid-decade census. Several bills were introduced in 1961 and subsequent years calling for a mid-decade census to be conducted every 10 years, such as H.R. 5993 introduced by Rep. Lesinski (D-MI) in the $88^{\text {th }}$ Congress. "Mid-Decade Census in 1965," 109 Cong. Rec. 7712 (May 2, 1963) (statement of Rep. Lesinski). Such legislation was supported particularly by state and local governments and businesses. Notable opponents included none other than Rep. Gallagher, who warned that the Census Bureau's ongoing efforts to improve data access by providing users with an "information system" would result in "a very complete and
} 
For example, in 1969, Sen. Sam Ervin introduced S. 1791 which would have made it unlawful for federal agencies to require individuals to disclose information unless the information was specifically authorized by the Constitution or an act of Congress. It also would have removed the penalties for not answering questions on the census "which have nothing to do with the purpose of the census." ${ }^{48}$ In September 1969, the House of Representatives approved H.R. 12884 to give Congress final authority over the questions on the decennial census and eliminate penalties for refusing to answer the census. The Senate took no action on the bill. ${ }^{149}$

In response to congressional concerns about the content of the 1970 census questionnaire, the Secretary of Commerce, Maurice Stans, made the following policy changes concerning the decennial census: (1) the Census Bureau would submit proposed questions to the appropriate congressional committees two years before Census Day, and (2) the agency would appoint more members of the general public to census advisory committees. In addition, the Secretary pledged to establish a blue-ribbon commission to examine issues related to the Census Bureau, including whether or not the census could be conducted on a voluntary basis. ${ }^{150}$

\subsection{Concerns over Privacy, Other Federal Data Banks}

In the meantime, Rep. Gallagher continued his investigation into invasions of privacy. In 1970, he noted that although his subcommittee on invasion of privacy had been successful in stopping the creation of the national data center, "many slightly less ambitious versions have been proposed and implemented," such as a nationwide Army data bank on protest activities of U.S. organizations. ${ }^{151}$ A year earlier, Rep. Jackson Betts had questioned the national welfare data bank and national job bank included in the proposed Family Assistance Act and Manpower Training Act. Betts noted that while he supported such concepts, it was important to carefully consider issues of privacy and confidentiality to ensure the data collected in government computers was not

thorough National Data Bank." "Gallagher Warns Against Census Bureau Data Bank," 113 Cong. Rec. 22336 (Aug. 10, 1967). Gallagher notes that trade associations and industries "have all expressed their sincere and profit-promising interest in census data" and social service organizations, planners, and social scientists have also indicated their great enthusiasm for a broader range of census questions and a wider range of data access." Ibid. Proposals for a mid-decade census would continue into the 1970s, and the 1976 amendments to Title 13 included the authority to conduct a mid-decade census. Mid-decade Census of Population, P.L. 94-521, 90 Stat. 2464, codified at 13 U.S.C.§141(d).

${ }^{148}$ Sen. Sam J. Ervin, "Announcement of Hearing: Privacy, the Census, and Federal Questionnaires," 115 Cong. Rec. 17719 (June 30, 1969). See Privacy, the Census, and Federal Questionnaires, hearings before the Subcomm. on Constitutional Rights, House Comm. on the Judiciary, 91 ${ }^{\text {st }}$ Cong., $1^{\text {st }}$ Sess., April 24-25; May 2; July 1, 1969. Three years earlier, The Wall Street Journal had called for congressional review of the "Bureau's broad power of compulsion." "Census Out of Hand," The Wall Street Journal, Aug. 29, 1966, reprinted at 112 Cong. Reg. 22709 (Sept. 15, 1966) (entered into the record by Sen. Long).

${ }^{149}$ Federal Data Banks and Constitutional Rights: A Study of Data Systems on Individuals Maintained by Agencies of the United States Government, Subcomm. on Constitutional Rights, Senate Comm. on the Judiciary, committee report, 93 $3^{\text {rd }}$ Congress, 1974, p. 13.

${ }^{150}$ Ibid., pp. 13-14. The commitment to submit proposed questions to Congress two years prior to Census Day was included in the 1976 amendments to Title 13 and codified at 13 U.S.C.§141(f)(2). 
misused. ${ }^{152}$

In 1974, it was the General Services Administration's (GSA) turn to be called "Big Brother." Since 1972, the agency had been planning a national computer network it called FEDNET. The network would have been expandable in order to provide affordable computing facilities for federal agencies. ${ }^{153}$ Congress and OMB expressed concern with the network, and Vice President Gerald R. Ford stated, "I am concerned that Federal protection of individual privacy is not yet developed to the degree necessary to prevent FEDNET from being used to probe into the lives of individuals." ${ }^{154}$ According to The Washington Post, "GSA officials profess[ed] astonishment at all the fuss." 155

Ultimately, congressional concern over data banks led to the passage of the Privacy Act. The Senate report accompanying S. 3418, which was signed into law as the Privacy Act of 1974, stated:

The Committee affirms that the present statutory division of executive branch power among the departments and agencies and bureaus promotes accountability and is most conducive to legislative oversight, Presidential management, and responsiveness to the public will. We believe that the creation of formal or de facto national data banks, or of centralized Federal information systems without certain statutory guarantees would tend to defeat these purposes, and threaten the observance of the values of privacy and confidentiality in the administrative process. ${ }^{156}$

In addition, the 1988 amendments to the Privacy Act, the Computer Matching and Privacy Protection Act, noted that the law should not be construed to authorize the establishment of "a national data bank that combines, merges, or links information on individuals" in systems of records maintained by federal agencies. ${ }^{157}$

\footnotetext{
${ }^{151}$ Rep. Cornelius E. Gallagher, "Gallagher Continues Computerized Information Systems Investigation with Letter to Secretary Resor on Allegations of an Army Domestic Surveillance Data Bank," 116 Cong. Rec. 1466 (Jan. 27, 1970).

${ }^{152}$ Rep. Jackson Betts, "National Welfare and Job Data Banks to Be Established in Legislation Before Congress," 115 Cong. Rec. 38166 (Dec. 10, 1969).

${ }^{153}$ Rep. Moss, "GSA Seeks to Play Big Brother," 120 Cong. Rec. 15037-15038.

${ }^{154}$ Gerald R. Ford, remarks before the National Computer Conference, May 1974, reprinted in 120 Cong. Rec. 15038-15039 (entered into the record by Rep. Moss).

155 "A Fight Over Data Banks," The Washington Post, June 18, 1974, reprinted in 120 Cong. Rec. 20821-20822 (June 24, 1974) (entered into the record by Rep. Edward I. Koch).

${ }^{156}$ Protecting Individual Privacy in Federal Gathering, Use and Disclosure of Information, S. Rep. No. 93-1183, 93rd Cong., 2nd Sess., Sept. 26, 1974, reprinted in U.S. Senate Comm. on Government Operations and House Comm. on Government Operations, Subcomm. on Government Information and Individual Rights, Legislative History of the Privacy Act of 1974, S. 3418 (Public Law 93-579), $94^{\text {th }}$ Cong., $2^{\text {nd }}$ Sess., joint committee print, Sept. 1976, p. 168.

${ }^{157}$ P.L. 100-503, 102 Stat. 2507 (October 18, 1988), The Computer Matching and Privacy Protection Act of $1988, \S 9$ (codified at 5 U.S.C. $\S 552 \mathrm{a}$, note).
} 


\subsection{Continuing Efforts at Statistical Coordination and Consolidation}

Although the national data center proposal faded away in 1969, discussions of how best to organize the federal statistical system continued. In August 1970, President Nixon established the President's Commission on Federal Statistics (referred to as the Wallis Commission). The Commission was charged with examining the problems that gave rise to the data center proposal, including issues related to the storage of and access to data. ${ }^{158}$ However, it stopped short of suggesting any sort of reorganization of the federal statistical system. One outcome was the creation of the Committee on National Statistics (CNSTAT) of the National Academy of Sciences. ${ }^{159}$

The Carter administration entered the debate with its own study group, the President's Project for the Federal Statistical System, also known as the Bonnen Commission. The group focused on five themes: (1) the perceived lack of relevance of federal statistical data, (2) threats to data integrity, (3) data quality, (4) privacy protection, and (5) paperwork burden. The members recommended the establishment of an enhanced Office of Statistical Policy within the Executive Office of the President to coordinate federal data collection. However, the Bonnen Commission's recommendations were not implemented. ${ }^{160}$

During the Reagan administration, there were several proposals to consolidate statistical agencies and improve efficiency of federal agencies. OMB and the departments of Labor and Commerce even discussed combining the Bureau of Labor Statistics with the Census Bureau (as had been proposed in the late 1960s). Similarly, in the early 1990s the administration of George H.W. Bush established a Working Group on Statistics chaired by Michael Boskin, the chairman of the Council of Economic Advisors. This group also examined statistical organization and considered combining the Census Bureau, BLS, the Bureau of Economic Analysis, and the National Agricultural Statistical Service. Ultimately, however, the working group concluded that cost savings from consolidation would be minimal. ${ }^{161}$

The issue of statistical centralization resurfaced again during the Clinton administration. For example, in 1995, Rep. Stephen Horn (R-CA) proposed H.R. 2521, the Statistical Consolidation Act, which would have combined the Census Bureau, BLS, and the Bureau of Economic Analysis. In 1996, recognizing the importance of data sharing, Rep. Horn proposed H.R. 3924, the Statistical Confidentiality Act, to provide uniform confidentiality protections across eight statistical agencies. ${ }^{162}$ In 1997, Sen. Daniel "Pat" Moynihan (D-NY) introduced S. 144 to establish a commission to study the consolidation of statistical agencies and Sen. Sam Brownback (R-KS) introduced S. 1404, the Federal Statistical System Act, to establish a Commission to Study the Federal Statistical System. In September 1998, the Subcommittee on Oversight of

\footnotetext{
${ }^{158}$ Arnold R. Weber, Office of Management and Budget, Draft Memorandum to the Director, re: Background on Proposal for a National Data Center, Oct. 22, 1970, p. 5.

${ }^{159}$ See Janet L. Norwood, Organizing to Count (Washington, D.C.: The Urban Institute Press, 1995), pp. 12-24.

${ }^{160}$ Ibid., pp. $16-18$.

${ }^{161}$ Ibid., pp. $18-20$.
} 
Government Management, Restructuring, and the District of Columbia of the Senate Committee on Governmental Affairs, considered Brownback's bill, renamed the Statistical Consolidation Act of 1998, but the bill did not receive approval from the full Senate. ${ }^{163}$

By the 2000s, the technological and political landscape had changed. The events of September 11, 2001 and the resulting USA PATRIOT Act renewed privacy concerns. Privacy proponents decried the monitoring of public library use, while others voiced suspicions that enforcement agencies would use government databases, such as those of the Social Security Administration and the Department of Education, for homeland security investigations. ${ }^{164}$ For example, a proposed Department of Justice program, Operation TIPS (Terrorism Information and Prevention System), which would have created a "national information sharing system for specific industry groups to report on publicly observable activity," was denounced by several groups on the grounds of invasion of privacy. ${ }^{165}$ The program was specifically prohibited by the Homeland Security Act of 2002 . $^{166}$

Despite privacy concerns, advances in computing technology continued. Between 1998 and 2009, the number of federal data computing centers grew from 432 to 1,100. By 2010, with the Privacy Act and other privacy protections in place, the government was less concerned with the privacy of the data centers (as it had been in the mid-1970s with the failure of FEDNET) than it was with efficiency and environmental concerns related to such centers. OMB concluded, "[t]his growth in redundant infrastructure investments is costly, inefficient, unsustainable and has a significant impact on energy consumption." 167 OMB directed agencies to conduct an inventory of data center assets and develop plans to consolidate data centers by mid-2010. In June 2010, Government Computer News noted that "[d]ata center consolidation simplifies operations, improves management and security issues." ${ }^{168}$ At the same time, federal agencies were also beginning to use "cloud computing" - services that enable agencies to use the Internet to share software, applications, and information - which resulted in renewed privacy

\footnotetext{
${ }^{162}$ Office of Management and Budget, Statistical Programs of the United States Government: Fiscal Year 1997, accessed at http://clinton3.nara.gov/omb/inforeg/stat97.html.

163 Statistical Consolidation Act of 1998, report of the Senate Comm. on Governmental Affairs to accompany S. 1404, $105^{\text {th }}$ Cong., $2^{\text {nd }}$ Sess., 1998.

${ }^{164}$ Joan Starr, "Libraries and National Security: An Historical Review," First Monday: PeerReviewed Journal on the Internet, vol. 9, no. 12 (Dec. 6, 2004), accessed at http://firstmonday.org; "A Chill in the Library," editorial, St. Petersburg Times, July 23, 2002; Laura Spadanuta, Kathryn Heinz, and Faith Okpotor, "Failed Homeland Security Programs," Aug. 29, 2006, accessed at News 21, A Journalism Initiative of the Carnegie and Knight Foundations, http://newsinitiative.org.

${ }^{165}$ Spadanuta, et al.; American Civil Liberties Union, "ACLU Says Bush Administration Should Not Allow Operations TIPS to Become An End Run Around the Constitution," press release, July 15, 2002; Jane Black, "Some TIPS for John Ashcroft," Business Week, July 25, 2002, accessed at http://www. businessweek.com; "Operation Tips Being Modified Following Criticism From Civil Liberties Groups," Fox News, Aug. 10, 2002, accessed at http://www.foxnews.com; Jordan Goldman, "Anti-Terror 'TIP' Program On Hold: Privacy Groups Fear It Would Prompt Us to Spy on Each Other," CBS News, Aug. 10, 2002, accessed at http://www.cbsnews.com/stories/2002/08/08/terror/main518088.shtml.

${ }^{166}$ Homeland Security Act of 2002, P.L. 107-296, 116 Stat. 2241 (Nov. 25, 2002), $\$ 880$.
} 
concerns. $^{169}$

In November 2010, OMB issued a memorandum for federal agencies concerning sharing data while protecting privacy. OMB strongly encouraged agencies "to engage in coordinated efforts to share high-value data for purposes of supporting important Administrative initiatives, informing public policy decisions, and improving program implementation while simultaneously embracing responsible stewardship." ${ }^{170}$ In particular, OMB noted the importance of data sharing and the use of data sets maintained by program, administrative, and regulatory offices and agencies in enhancing the federal government's "ability to contain costs and reduce burdens on respondents, while increasing the quality and quantity of statistical information..." 171 In fact, the President's proposed FY 2011 budget request included $\$ 9$ million for improving the Census Bureau's administrative records infrastructure and enhancing the federal statistical system's ability to use administrative records. ${ }^{172}$

\section{Conclusions}

When the national data center proposal first came to the attention of members of Congress, their main concern was with potential invasions of privacy. Congress feared that combining many data sets into one central computer would make it easier to identify personal information about individuals. In addition, some members were worried that the types of data collected on individuals would be limitless and could include erroneous or misleading information. In fact, one of the key issues of the national data center controversy centered on what would and would not be included in the data center. The original proposals contained few details on this topic, allowing the public imagination to fill in the blanks.

Congressional concerns were brought to the attention of the public through news reports on hearings held by Congress. Soon, others joined the discussion. Among these were social scientists who supported the data center proposal and others who urged

\footnotetext{
${ }^{167}$ Vivek Kundra, federal chief information officer, OMB, Memorandum for Chief Information Officers, re: Federal Data Center Consolidation Initiative, Feb. 26, 2010. OMB had issued a similar directive in 1995. Office of Management and Budget, Bulletin No. 96-02, Consolidation of Agency Data Centers, Oct. 4, 1995.

${ }^{168}$ Rutrell Yasin, "The Political Hurdle to Data Center Consolidation," Government Computer News, June 8, 2010, accessed at http://www.gcn.com.

${ }^{169}$ Emily Long, "FCC: Agencies Need Common Cloud Computing Vision," March 3, 22, 2010, accessed at http://www.nextgov.com. See also Robert Gellman, "Privacy in the Clouds: Risks to Privacy and Confidentiality from Cloud Computing," paper prepared for the World Privacy Forum, Feb. 23, 2009.

170 Jeffrey D. Zients, deputy director for management, Office of Management and Budget, and Cass R. Sunstein, administrator, Office of Information and Regulatory Affairs, Memorandum for the Heads of Executive Departments and Agencies, re: Sharing Data While Protecting Privacy, MM-11-02, Nov. 3, 2010, http://wWw.whitehouse.gov/sites/default/files/omb/memoranda/2011/m11-02.pdf, p. 1.

${ }^{171}$ Ibid., p. 2.

${ }^{172}$ Office of Management and Budget, Budget of the U.S. Government: Fiscal Year 2011, appendix, p. 209, accessed at http://www.whitehouse.gov/omb. See also Population Association of America, "Update on President's FY 2011 Budget," July 20, 2010, accessed at http://www.populationassociation. org/2010/07/20/filesupdatefy2011presidentsbudget-pdf/.
} 
caution and careful study concerning privacy implications. Data center proponents were able neither to quell the fears expressed by the various interests nor convince the public of the usefulness of their plan. In fact, they seemed to be surprised at the chaos caused by their suggestion to make the federal statistical system more efficient. A few years after the uproar subsided, Edgar Dunn noted:

During the period, I felt very much as though I were playing the lead in a Chaplinesque movie. Enter the innocent college professor who becomes involved in an improbable series of events, bumbling along from one incident to the next, never fully comprehending what is going on... I was caught in a social dynamic that made it impossible to reconcile, for the public image, the multiple goals and objectives that, in a more dispassionate milieu, could have quite reasonably been dealt with. It was a situation in which both the language and intentions of the report were widely misconstrued. ${ }^{173}$

Indeed, Rep. Gallagher, in an address to Congress, noted that the proponents of the national data center "seemed unable to comprehend" how a data center could be turned into "a personal dossier center" and the power such a center would have. ${ }^{174}$ He further charged that computer scientists, behavioral scientists, and experts in constitutional law and civil liberties did not communicate with one another, concluding "[w]e can no longer afford isolated contemplation in this area." ${ }^{175}$ Similarly, Arthur Miller, who had advocated for privacy safeguards at several of the data center hearings stated, "...even when the situation is viewed most charitably, it still is shocking that high ranking government officials and prominent behavioral scientists were so preoccupied with the quantity of information and the data processing capabilities the center would put at their disposal, that they were virtually insensitive to the privacy question." 176 Even The New York Times noted: "most Government statisticians seemed astonished that anyone might question their motives or doubt that they had the public's interests at heart." 177

\footnotetext{
${ }^{173}$ Edgar S. Dunn, Social Information Processing and Statistical Systems-Change and Reform (New York: John Wiley \& Sons, 1974), p. 175. In addition, Dunn allowed that "At the same time the threat to personal privacy, although distorted and exaggerated, was a legitimate issue." Ibid.

${ }^{174}$ Cornelius Gallagher, "Questions of Invasion of Privacy Relating to the Establishment of a National Data Center," 112 Cong. Rec. 19963 (Aug. 18, 1966).

${ }^{175}$ Ibid.

${ }^{176}$ Arthur R. Miller, The Assault on Privacy: Computers, Data Banks, and Dossiers (Ann Arbor, MI: The University of Michigan Press, 1971), p. 58.

${ }^{177}$ Nan Robertson, "Data Bank: A Threat to Your Privacy?" The New York Times, Jan. 7, 1968, reprinted in 114 Cong. Rec. 25199-25200 (submitted to the record by Rep. Gallagher). At least some in the statistical community acknowledged this conundrum. For example, in his presidential address to the American Statistical Association several years later, Lester R. Frankel acknowledged that "[b]ecause of our training to be objective and to think in abstract terms, we tend to regard the consequences of our work in an impersonal manner." Lester R. Frankel, "Statistics and the People-The Statistician's Responsibilities," Journal of the American Statistical Association, vol. 71, no. 353 (March 1976), p. 9. Frankel's speech focused on statisticians' responsibilities concerning: proper use of statistical methods, such as sampling; confidentiality; and the safety of respondents. He added, "[p]erhaps we are not treating the respondent with respect, as a human being. There is a tendency among statisticians to regard the person as only incidental to the information about the person. Statisticians are taught to think this way." Ibid., p. 12.
} 
Although the national data center was rejected, researchers both within and outside of federal statistical agencies continued their work on improving statistical information, integrating data sets, and expanding their use for research. Further, during the past four decades, computer technology has advanced dramatically. The Internet, cloud computing, wireless communications, and social media present new concerns about privacy. The public remains wary of government programs, including those of the federal statistical system. But then, not even the census of 1790 was free from public scrutiny. Those who opposed to the census argued "it would excite the jealousy of the people; they would suspect that the Government was too particular... they may refuse to give the officer such a particular account as the law requires..."178 What would such skeptics say today?

\section{Appendix}

Archival materials from the Bureau of the Budget were obtained from the Records of the Office of Management and Budget, Record Group 51, at the National Archives at College Park, College Park, MD. Unpublished documents from the U.S. Census Bureau were obtained from the Census Bureau History Staff in Suitland, MD.

\footnotetext{
${ }^{178}$ Quoted in David J. Seipp, "The Right to Privacy in American History," July 1978, publication P-78-3, Program on Information Resources Policy, Harvard University, p. 18.
} 


\section{References}

[1] Computer Matching and Privacy Protection Act of 1988. § 9, P.L. 100-503, 102 Stat. 2507 (October 18) (codified at 5 U.S.C. $\S 552 \mathrm{a}$, note).

[2] (1966). Privacy Subcommittee Brings a Sense of Balance to Technological Growth and the Right to Privacy. Entered into record by Rep. Gallagher, 112 Cong. Rec. 28688-28705.

[3] Duncan, J. W. and Shelton, W. C. (1978). Revolution in the United States Government Statistics: 1926-1976. U.S. Department of Commerce, Office of Federal Statistical Policy and Standards.

[4] Dunn, E. S. (1974). Social Information Processing and Statistical Systems-Change and Reform. New York: John Wiley \& Sons.

[5] Gallagher, C. (1966). Questions of Invasion of Privacy Relating to the Establishment of a National Data Center. 112 Cong. Rec. 19963.

[6] - (1967). The Federal Data Center and the Invasion of Privacy - A Progress Report. 113 Cong. Rec. 6747.

[7] - (1967). Privacy and the National Data Center. Speech before the Joint Computer Conference, Atlantic City, NJ, April 18, 1967. Reprinted in 113 Cong. Rec. 29590.

[8] Kanter, J. (1969). The census under attack. The American Sociologist, 4(3): 256.

[9] Kaysen, C., Holt, C. C., Holton, R., Kozmetsky, G., Morrison, H. R., and Ruggles, R. (1969). Report of the task force on the storage of and access to government statistics. Reprinted in The American Statistician, 23(3): 11-19.

[10] Norwood, J. L. (1995). Organizing to Count. Washington, D.C.: The Urban Institute.

[11] Office of Management and Budget (2010). Memorandum re: Federal Data Center Consolidation Initiative. Feb. 26.

[12] Robertson, N. (1968). Data bank: A threat to your privacy. The New York Times. Jan. 7, reprinted in 114 Cong. Rec. 25200.

[13] Rubin, E. E. (1968). Census programs attacked as invasions of privacy. The American Statistician, 22(2): 12-13.

[14] Social Science Research Council (1965). Report of the Committee on the Preservation and Use of Economic Data.

[15] U.S. Congress (1967). The coordination and integration of government statistical programs. Hearings before the Subcommittee on Economic Statistics, Joint Economic Committee, $90^{\text {th }}$ Cong., $1^{\text {st }}$ Sess., May 17-18, June 7-8. 
[16] U.S. House of Representatives (1966). The computer and invasion of privacy. Hearings before the Special Subcommittee on Invasion of Privacy, House Committee on Government Operations, $89^{\text {th }}$ Cong.

[17] - (1967). Hearings on H.R. 10952. Committee on Post Office and Civil Service, $90^{\text {th }}$ Cong., $1^{\text {st }}$ Sess.

[18] U.S. Senate (1966). Invasions of privacy. Hearings before the Subcommittee on Administrative Practice and Procedure, Committee on the Judiciary, $89^{\text {th }}$ Cong., $2^{\text {nd }}$ Sess., Mar. 23-30, June 7-16.

[19] — (1974). Federal data banks and constitutional rights: A study of data systems on individuals maintained by agencies of the united states government. Committee on Judiciary, Subcommittee on Constitutional Rights, $93^{\text {rd }}$ Cong.

[20] U.S. Senate, Committee on Government Operations and U.S. House of Representatives, Committee on Government Operations, Subcommittee on Government Information and Individual Rights (1976). Legislative history of the privacy act of 1974, S. 3418 (Public Law 93-579). 94 ${ }^{\text {th }}$ Cong., $2^{\text {nd }}$ Sess., joint committee print.

[21] Voight, R. B. (Bureau of the Census) (1967). Developments in making census data more useful. Paper given at the Federal Statistics User Conference, Washington, D.C., Oct. 20.

[22] Yasin, R. (2010). The political hurdle to data center consolidation. Government Computer News. June 8.

[23] Zients, J. D. and Sunstein, C. R. (2010). Memorandum for the Heads of Executive Departments and Agencies, re: Sharing Data While Protecting Privacy. Nov. 3. 
